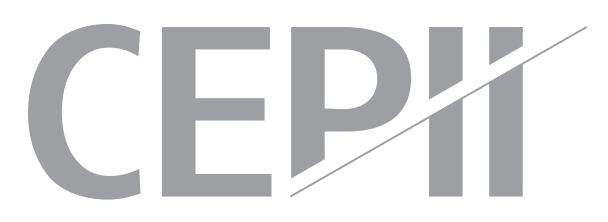

\title{
Currency Misalignments and Exchange Rate Regimes in Latin American countries: A Trade-Off issue
}

Jorge Carrera, Blaise Gnimassoun, Valérie Mignon

\& Romain Restout

Highlights

- Latin American countries face a key trade-off in their choice of exchange rate regime: sizeable but less persistent misalignments, and long-lasting but weaker currency imbalances.

- While fixed exchange rate regimes have the advantage of reducing the size of misalignments, they accentuate their persistence.

- Misalignments are higher under flexible exchange rate regimes, but are less persistent.

- We show that flexible regimes permit a faster correction of currency imbalances. 


\section{Abstract}

This paper conducts an in-depth empirical investigation on the impact of the exchange rate regime (ERR) on real currency misalignments in a panel of 17 Latin American countries over the 1970-2016 period. We consider explicitly the two dimensions of misalignments, size and persistence, and evaluate four different ERR classifications. We also pay attention to cross-sectional dependencies across countries that appear to be important in Latin America, and provide several robustness checks. Our main findings show that, although fixed ERR perform well in limiting the size of misalignments - and in reducing inflation and fiscal deficit - the disequilibria are more persistent. On the contrary, allowing for more flexibility reduces persistence but increases the size of misalignments. Overall, we show that Latin American countries face a crucial trade-off when they have to choose their ERR.

\section{Keywords}

Latin American Countries, Exchange Rate Regimes, Currency Misalignments.

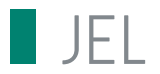

F31, C23, E42.

\section{Working Paper}

CEPII (Centre d'Etudes Prospectives et d'Informations Internationales) is a French institute dedicated to producing independent, policyoriented economic research helpful to understand the international economic environment and challenges in the areas of trade policy, competitiveness, macroeconomics, international finance and growth.

CEPII Working Paper
Contributing to research in international
economics
@ CEPII, PARIS, 2020
All rights reserved. Opinions expressed
in this publication are those of the
author(s) alone.

Editorial Director: Sébastien Jean

Production: Laure Boivin

Published on 16.04 .20

No ISSN: $1293-2574$
CEPII

20, avenue de Ségur TSA 10726 75334 Paris Cedex 07 +33153685500 www.cepii.fr Press contact: presse@cepii.fr 


\title{
Currency misalignments and exchange rate regimes in Latin American countries: a trade-off issue*
}

\author{
Jorge Carrera ${ }^{\dagger} \quad$ Blaise Gnimassoun ${ }^{\ddagger}$ \\ Valérie Mignon ${ }^{\S} \quad$ Romain Restout $\mathbb{I}$
}

\section{Introduction}

The role of the nominal exchange rate in Latin American economies has evolved markedly over the last half-century. In the first part of the period, although it served as the main anchor of nominal stability, it was also the primary source of economic and financial crises. In recent decades, its capacity to absorb changes in external conditions has grown in a context of more open and stable economies. Concurrently, over the whole period, the dynamics of the real effective exchange rates in the region were characterized by large swings, strong volatility, and persistent misalignments. Such sustained deviations of the real exchange rate from its equilibrium level are likely to produce severe macroeconomic disequilibria, whose resorption requires successful stabilization policies and exchange rate management. Within this context, the choice of exchange rate regime (ERR) appears to be a key issue. Indeed, various macroeconomic outcomes, such as inflation, unemployment,

*This paper has previously been circulated as 'Long Run Determinants of Real Exchange Rates in Latin America'. We thank Carl Grekou, Sébastien Jean, Esteban Rodriguez, Mariano Sardi, Fernando Toledo and Pablo de la Vega for very useful comments. The usual disclaimers apply. Corresponding author: Valérie Mignon, University of Paris Nanterre, EconomiX-CNRS, 200 avenue de la République, 92001 Nanterre cedex, France. Tel.: 331409758 60. E-mail: valerie.mignon@parisnanterre.fr.

†University of La Plata, and CONICET, Argentina. E-mail: jorge.carrera@econo.unlp.edu.ar

$\ddagger$ University of Lorraine, BETA, CNRS, INRA, 54000, Nancy, and EconomiX, France. E-mail: blaise.gnimassoun@univ-lorraine.fr

$\S$ EconomiX-CNRS, University of Paris Nanterre, and CEPII, Paris, France. E-mail: valerie.mignon@parisnanterre.fr

I University of Lorraine, BETA, CNRS, INRA, 54000, Nancy, France, and IRES, Belgium. Email: romain.restout@univ-lorraine.fr 
financial and balance of payment crises, as well as episodes of rapid growth, are mainly influenced by exchange rate policies and regimes (see Rodrik, 2008; Frenkel and Rapetti, 2010; and Martin Guzman and Stiglitz, 2018).

This paper aims at addressing this critical question by investigating the impact of ERR on real currency misalignments, i.e., on the deviations of the real exchange rate from its equilibrium value. Since currency imbalances have a strong influence on the macroeconomic performance of countries, the level of the real exchange rate matters greatly. In particular, Latin American countries have experienced several overvaluation episodes that have had detrimental effects on economic growth. The choice of ERR plays a key role in that regard. Argentina and its fixed ERR provide a typical example in the 1990s, as the massive Argentina peso overvaluation plunged the country into a great depression. However, the movement towards more flexibility in the ERR has also strongly affected countries' macroeconomic results, as illustrated by the Chilean case during the 1970s. Hence, the choice of ERR is far from being straightforward.

From a theoretical viewpoint, two main explanations have been put forward regarding the link between ERR and currency misalignments. On the one hand, Friedman (1953) states that flexible exchange rates encourage price convergence across countries, even where the prices of goods are rigid. In that context, changes in the nominal exchange rate substitute for nominal price adjustments. On the other hand, under fixed ERR, transaction costs are reduced and cross-border trade is enhanced in the goods market. Price convergence is thus fostered as the transparency of price differentials that could be arbitraged away is increased (Rose, Lockwood, and Quah, 2000). Turning to the empirical literature, here too the results are not clear-cut regarding the impact of ERR on misalignments. Dubas (2009) considers a panel of 102 countries and shows that for developing economies, intermediate regimes (regimes falling somewhere between a pure float and a hard peg) are more effective in reducing the size of misalignments. Conversely, Nouira and Sekkat (2015) find that intermediate ERR tend to generate larger and more volatile misalignments. For their part, Coudert and Couharde (2009) find that misalignments are higher in the case of fixed ERR, and Holtemoller and Mallick (2013) show that the higher the flexibility of the regime, the lower the misalignment and, thus, the probability of an impending crisis. These diverging conclusions are partly due to differences in the selected samples, and call for more "targeted" studies dealing with countries characterized by specific experiences like those of Latin America. Furthermore, although these aforementioned studies investigate the effect of ERR on the size of misalignments, they are silent on its impact on their persistence.

This paper falls into this strand of the literature, to which we contribute in several ways. First, we consider a sample of 17 Latin American countries over quite a long 
time-span, allowing us to account for various exhaustive exchange rate arrangements within the sample period. Given the continuous changes in exchange rate policy linked to macroeconomic imbalances in this region, our sample is especially relevant for empirical purposes. Second, we rely on a robust approach to derive currency misalignments by considering (i) the main relevant exchange rate determinants, and (ii) cross-country dependencies through the use of effective (i.e., multilateral) exchange rates and appropriate panel estimation methods. ${ }^{1}$ Third, whereas the existing literature mainly relies on one or two of the usual ERR classifications, we consider four different classifications, including one that we define as consensual. Fourth, in addition to investigating the effect of ERR on the size of misalignments, we also rigorously analyze its impact on their persistence. In doing so, our paper is, to the best of our knowledge, the first to consider explicitly the two dimensions of misalignments, size and persistence, when assessing the impact of the EER on deviations of the real exchange rate from its equilibrium value. Finally, turning to methodological issues, we pay particular attention to cross-sectional dependencies across countries and provide several robustness checks.

Our main findings show that although fixed ERR perform well in limiting the size of misalignments, the disequilibria are more persistent. On the contrary, allowing for more flexibility reduces persistence, but increases the size of misalignments. Overall, we show that Latin American countries face a crucial trade-off when they have to choose their ERR.

The rest of the paper is organized as follows. Section 2 presents our methodology and describes the data. Section 3 displays the estimation results, and related comments. Section 4 provides several robustness checks, and Section 5 concludes the paper.

\section{Methodology and data}

\subsection{Estimating exchange rate misalignments}

Commonly defined as the deviations of real effective exchange rates from their equilibrium values, currency misalignments can be derived from the following equation:

$$
\operatorname{mis}_{i, t}=\operatorname{reer}_{i, t}-\widehat{\text { reer }}_{i, t},
$$

\footnotetext{
${ }^{1}$ In this regard, we go further than previous studies on currency misalignments in Latin American countries, which typically focused on (i) one specific country or a quite limited sample of economies (see, e.g., Buchs, 2005, and Paiva, 2006, on Brazil; Giannellis and Koukouritakis, 2013, on a panel of four countries), and/or (ii) a limited number of exchange rate determinants (Alberola, 2003; Fernando Broner, 2005; Chi-Wei Su and Chang, 2011).
} 
where $i$ and $t$ refer to the cross-section unit (country) and the time unit (year), respectively. mis denotes the currency misalignment, reer stands for the real effective exchange rate (in logarithmic terms), and $\widehat{r e e r}$ is its corresponding equilibrium level. An increase (decrease resp.) in reer denotes an appreciation (depreciation resp.) of the real exchange rate, a positive (negative resp.) value of misalignment refers to a currency overvaluation (undervaluation resp.). To assess this equilibrium value, various approaches exist in the literature, among which the most popular are (i) the purchasing power parity (PPP) approach which is relevant only in the very longrun (see Rogoff, 1996), (ii) the medium-run, fundamental equilibrium exchange-rate approach (FEER) of Williamson (1983), and (iii) in -between, the behavioral equilibrium exchange-rate approach (BEER) introduced by Faruqee (1995) and MacDonald and Clark (1998). ${ }^{2}$ As shown by Bénassy-Quéré, Béreau, and Mignon (2010), these various approaches can be seen as complementary rather than opposite in the sense that each of them corresponds to a particular horizon. In this paper, we rely on the BEER methodology that has the double advantage of (i) not requiring assumptions regarding the internal and external balances, and (ii) accounting for stock effects through the net foreign asset position.

According to the BEER approach, the real effective exchange rate of country $i$ at period $t$ is linked to a set of economic fundamentals through a cointegrating relationship defined as follows:

$$
\text { reer }_{i, t}=f\left(n f a_{i, t}, b_{i, t}, \text { tot }_{i, t}, \text { open }_{i, t}, \text { gov }_{i, t}\right) \text {, }
$$

with $i=1, \ldots, N$ and $t=1, \ldots, T$. Equation (2) includes the following explanatory variables:

- The net foreign asset position as a percentage of GDP, $n f a_{i t}$. This variable is expected to have a positive impact on the real effective exchange rate, both series being related through the intertemporal budget constraint which links external assets, real exchange rate and trade balance together (see, e.g., Lane and Milesi-Ferretti, 2002). A country running a current account deficit (surplus resp.) is expected to experience a depreciated (appreciated resp.) real exchange rate to restore external equilibrium.

- A measure of relative (tradable versus non-tradable sectors) productivity as a proxy for the Balassa-Samuelson effect, $b s_{i t}$, expressed as a logarithm. We retain here the relative GDP per capita to proxy productivity, which is available

\footnotetext{
${ }^{2}$ See Driver and Westaway (2005) for a survey. For a discussion on the validity of PPP for developing countries, including Latin American economies, see Edwards and Savastano (1999) and Nouira and Sekkat (2015) among others.
} 
for a wide range of countries. As for the preceding variable, the relationship between reer $_{i t}$ and $b s_{i t}$ is expected to be positive as the Balassa-Samuelson effect reflects the convergence process of a country resulting in an appreciation of its real exchange rate through greater productivity growth in the domestic tradable sector.

- Terms of trade, tot ${ }_{i t}$, expressed as a logarithm. The impact of changes in terms of trade on the real effective exchange rate is not clear-cut at first sight in the sense that two effects are at play, a substitution and an income effect, acting in opposite directions (De Gregorio and Wolf, 1994). According to the substitution effect, an improvement in the terms of trade (i.e., an increase in the price of exports relative to imports) leads domestic agents to shift their demand towards imported goods. The impact on the exchange rate is negative as the currency has to depreciate to restore the external equilibrium. Regarding the income effect, an improvement in the current account position tends to increase demand for non-tradable goods. As a consequence, prices in the non-tradable sector augment as well as the general price level, appreciating the real exchange rate.

- Trade openness, open $_{i t}$, expressed as a percentage of GDP. Again, the influence of trade openness on the exchange rate is quite ambiguous due to the existence of substitution and income effects, operating in opposite directions (see, e.g., Edwards, 1989).

- Government spending, denoted as gov $v_{i t}$ and expressed as a percentage of GDP. According to Froot and Rogoff (1995), this variable positively impacts the real exchange rate through the direct effect it exerts on the prices of non-tradable goods. This explanation has been called into question by Ravn, SchmittGrohé, and Uribe (2012), arguing that a rise in government spending stimulates private consumption, in turn, depreciating the real exchange rate.

\subsection{Explaining exchange rate misalignments}

Once the series of currency misalignments have been calculated, a key issue is to assess whether the ERR impacts their size and persistence. To this end, we rely on two models of different but complementary natures, each of them having a specific purpose.

Theoretically, the stability of the international monetary system requires national monetary balances (absence of misalignments) or weak controllable monetary distortions (small misalignments). Similarly, large currency misalignments are also 
undesirable at the national level since they often hide significant economic distortions. Therefore, we assess the impact of the ERR on the size of misalignments through the following static model:

$$
\left|m i s_{i, t}\right|=\alpha_{0}+\alpha_{1} E R R_{i, t}+\sum_{l=1}^{k} \delta_{l} X_{i, t}^{l}+\epsilon_{i, t},
$$

where $\mid$ mis $\mid$ represents the absolute value of the misalignment, $E R R$ denotes the exchange rate regime, and $X$ is a vector of $k$ control variables regrouping the level of financial development, the quality of institutions, changes in the terms of trade (in absolute terms), and a dummy variable to account for crises. Equation (3) is similar to that in Dubas (2009), but with additional controls (quality of institutions and terms of trade variations). ${ }^{3}$ To the extent that countries with strong political and financial institutions experience fewer political or monetary crises, or manage them more effectively, they are likely to exhibit smaller exchange rate misalignments. Thus, we expect negative coefficients associated with the quality of institutions and financial development variables. In addition, currency misalignments are potentially larger in countries facing more pronounced terms of trade shocks (Amano and van Norden, 1995; Mendoza, 1995; Devereux and Connolly, 1996). For Latin American countries, Zeev, Pappa, and Vicondoa (2017) show that variations in the terms of trade are an important and indisputable determinant of economic fluctuations. We expect a positive coefficient associated with terms of trade changes (in absolute terms). Finally, we include a crisis indicator among the control variables to take into account the years of banking crises which are periods characterized by larger currency misalignments. ${ }^{4}$ Since ERR are classified from the most fixed to the most flexible, an estimated positive value for $\alpha_{1}$ would mean that the more flexible the EER, the larger the currency misalignments.

Besides their size, the persistence of misalignments is also a major concern in emerging and developing countries. Indeed, long-lasting misalignments may reflect persistent economic distortions requiring structural reforms and, sometimes, significant adjustment costs. To examine whether the ERR influences the persistence of misalignments, we consider the following dynamic model:

$$
m i s_{i, t}=\beta_{0}+\beta_{1} m i s_{i, t-1}+\beta_{2} E R R_{i, t}+\beta_{3} m i s_{i, t-1} \times E R R_{i, t}+\sum_{l=1}^{k} \delta_{l} X_{i, t}^{l}+\mu_{i, t} .
$$

\footnotetext{
${ }^{3}$ In the same vein, see also Gnimassoun (2015) for current account imbalances.

${ }^{4}$ Recall that the classifications of Shambaugh (2004) and Ilzetzki, Reinhart, and Rogoff (2019) are based on the volatility of the exchange rate. We therefore eschew the use of a currency crises dummy as a control variable because, within the present context, an exchange rate crisis indicator is strongly correlated with discrete changes in the ERR.
} 
The dependent variable now refers to the misalignment, and its lagged value is included among the explanatory variables to measure the degree of persistence. The interaction between mis and ERR allows us to examine whether the ERR impacts the persistence of misalignments. The control variables are the same as before, with the terms of trade now being expressed in level due to the nature of the dependent variable.

Equation (4) has often been used to test the relevance of Friedman (1953)'s argument that the flexibility of the nominal exchange rate allows for a more effective adjustment of external imbalances (see, among others, Chinn and Wei, 2013; Martin, 2016; Ghosh, Qureshi, and Tsangarides, 2018). To our knowledge, only Caputo (2015) attempts to assess the effect of ERR on the persistence of misalignments. However, the related empirical treatment may be questioned since the dependent variable considered in this study is the change in the real effective exchange rate rather than the misalignments themselves. In Equation (4), the coefficient of the interaction term $\left(\beta_{3}\right)$ deserves particular attention. Given the ERR classification, a positive sign for $\beta_{3}$ would indicate that the flexibility of the ERR increases the persistence of misalignments. Conversely, a negative sign would mean that flexible ERR are more effective in ensuring a quick adjustment of currency misalignments. Although several studies confirm Friedman's argument, the consensus is far from being definitive. For example, Berka, Devereux, and Engel (2012) show that real exchange rate movements within the Eurozone are at least as compatible with efficient adjustment as the behavior of real exchange rates for floating countries outside the euro area.

\subsection{Exchange rate regime classifications}

As is standard in the international macroeconomics literature, we rely on the de facto ERR classification when investigating how the ERR affects the size and persistence of currency misalignments. De jure classifications are based on the declared status of countries. However, it is now well accepted that a de facto measure is more reliable than a de jure one since, in practice, countries may have incentives to deviate from their officially declared intention. In this paper, we consider two of the best known and most widely used classifications, i.e., those of Shambaugh (2004) (henceforth SHA) and Ilzetzki, Reinhart, and Rogoff (2019) (henceforth IRR). ${ }^{5}$

Shambaugh (2004) bases his classification exclusively on the degree of exchange rate stability: the regime is considered as a peg if the exchange rate remains within \pm 2 percent bands against the reference currency; otherwise the regime is treated as non-

\footnotetext{
${ }^{5}$ For the sake of robustness, other classifications will be considered further in the paper.
} 
peg. This methodology is highly transparent in its construction and delivers a clearcut and dichotomous classification: the ERR of a given country-year observation is labeled as either peg (for which the dummy variable takes the value of zero) or non-peg (the index is one). ${ }^{6}$ In addition, this two-way classification of Shambaugh (2004) has good coverage for 16 out of the 17 countries contained in our sample (Ecuador is the exception) over the 1970-2014 period.

Ilzetzki, Reinhart, and Rogoff (2019) built their classification by also relying on the variability of exchange rates. However, their method is enriched by considering: (i) data on consumer price indices' movements to identify high inflation periods, (ii) countries' regime announcements (the de jure status) of which are not always consistent with the de facto approach, and (iii) the existence of dual exchange rate arrangements and/or parallel markets whenever they exist. In our context, considering exchange rate data coming from parallel exchange rate markets when categorizing regimes is particularly relevant, as such markets accounted for a large part of exchange rate developments in Latin America during the debt crisis of the 1980s. The IRR classification includes 14 categories in which a regime may fall (from more to less fixity). To improve identification, we collapse this large number of categories into a three-way classification with the value 1 for the fixed regime (from "no legal tender" to "de facto peg"), 2 for the intermediate regime (from "pre-announced crawling peg" to "moving band that is narrower than or equal to $\pm 2 \%$ "), and 3 for the floating regime ("managed floating" to "freely falling"). Besides, the IRR measure covers all countries in our sample over our reference period 1970-2016.

Figure 1 presents the share of fixed ERR for a group of 16 Latin American countries over the last four and a half decades. ${ }^{7}$ On the left (right resp.) panel, we plot the share of fixed regimes according to the SHA (IRR resp.) classification for the full sample of Latin American countries, together with South American countries and Central American countries separately. ${ }^{8}$ As shown, fixed exchange rates are more prevalent among Central American countries than in South America, and this picture is similar across decades and different classifications. We acknowledge this

\footnotetext{
${ }^{6}$ In Shambaugh (2004), the original ranking is $\mathrm{peg}=1$ and non-peg $=0$. Throughout the paper, the two categories are reversed (i.e., $p e g=0$ and non-peg=1) such that the SHA index is ordered in a monotonic way from more to less fixity. This choice is made so that the ordering of the SHA classification is consistent with that of the IRR database, see below.

${ }^{7}$ For the sake of comparability, we restrict our attention to a group of countries (Argentina, Bolivia, Brazil, Chile, Colombia, Costa Rica, Dominican Republic, Guatemala, Honduras, Jamaica, Mexico, Panama, Paraguay, Peru, Trinidad and Tobago, and Uruguay) and a period of time (19702014 ) that are comparable across the two classifications. This means we omitted Ecuador and observations for the years 2015 and 2016 for all countries when considering the IRR classification.

${ }^{8}$ Fixed ERR concern regimes with a value of 0 in the SHA classification, and 1 in the IRR classification.
} 
Figure 1: Percentage of Fixed Exchange Rate Regimes in Latin American Countries (SHA classification on the left panel and IRR classification on the right panel).
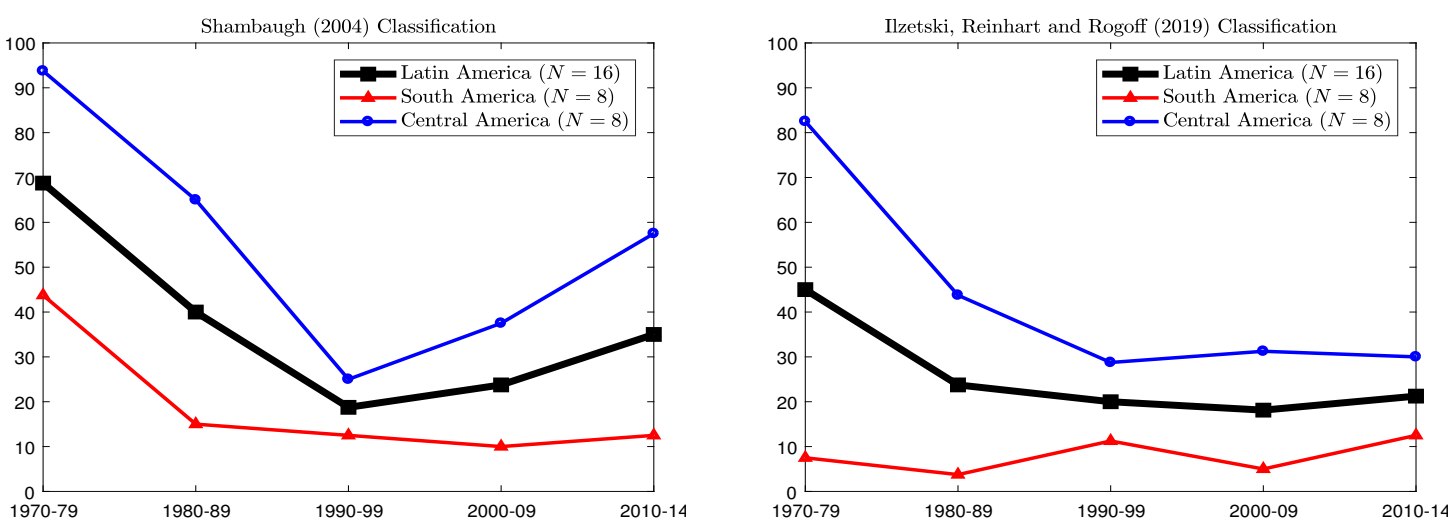

Note: The group of 16 Latin American countries comprises 8 South American countries

(Argentina, Bolivia, Brazil, Chile, Colombia, Paraguay, Peru, and Uruguay) and 8 Central American countries (Costa Rica, Dominican Republic, Guatemala, Honduras, Jamaica, Mexico, Panama, and Trinidad and Tobago). Period: 1970-2014.

issue, and address it in the robustness section (see Section 4.2). In addition, for the whole sample, the percentage of fixed ERR has declined over time from $69 \%$ in the 1970 s to $35 \%$ in the 2010 decade according to the SHA classification (the corresponding numbers for the IRR classification are $45 \%$ and $21 \%$ respectively). This pattern remains valid for both groups of countries. The declining share of fixed ERR over time on the Latin American continent may reflect continuous adjustments in exchange rate policy - as illustrated by the increasing adoption of inflation targeting strategy - to deal with macroeconomic imbalances.

\subsection{Data}

We consider a wide panel of 17 Latin American countries: Argentina, Bolivia, Brazil, Chile, Colombia, Costa Rica, Dominican Republic, Ecuador, Guatemala, Honduras, Jamaica, Mexico, Panama, Paraguay, Peru, Trinidad and Tobago, and Uruguay. ${ }^{9}$ The baseline period runs from 1970 to 2016, and data are annual.

Let us first describe the data used to estimate Equation (2). The real effective exchange rate for country $i$ at time $t, R E E R_{i, t}$, is constructed as the geometric

\footnotetext{
${ }^{9}$ Note that El Salvador, Haiti, Nicaragua, and Venezuela are excluded from our sample due to either data availability issues or to the fact that they have known only one ERR over the whole period (such as El Salvador for instance, whose currency was pegged to the U.S. dollar over the period under study).
} 
weighted average of the real bilateral exchange rates vis-à-vis its ten main trading partners:

$$
R E E R_{i, t}=\prod_{j=1}^{10}\left(\frac{P_{i, t}}{E_{i j, t} P_{j, t}}\right)^{\omega_{j, t}},
$$

where $P_{i, t}$ and $P_{j, t}$ are domestic and foreign consumer price indexes, respectively, and $E_{i j, t}$ is the nominal exchange rate (in units of domestic currency). $\omega_{j, t}$ is the trade weight of partner $j$ in total trade of the home country $i$. Prices and nominal exchange rates series are taken from the IMF International Financial Statistics database. Trade weights are constructed using countries' export and import data from the IMF Direction of Trade Statistics database.

The variable $R E E R_{i, t}$ is expressed as an index $(100=2000)$ and then converted into logarithms such that reer $_{i, t}=\ln \left(R E E R_{i, t}\right)$. According to our definition, an increase in reer $_{i, t}$ corresponds to a real appreciation. The variable $n f a_{i, t}$ is constructed as the ratio of the net foreign assets position to GDP, both expressed in U.S. dollars (source: Lane and Milesi-Ferretti (2001), and updates thereto). Due to the lack of data on sectoral productivity, GDP per capita relative to trading partners is used as a proxy for the Balassa-Samuelson effect:

$$
B S_{i, t}=\prod_{j=1}^{10}\left(\frac{y_{i, t}}{y_{j, t}}\right)^{\omega_{j, t}},
$$

where $y_{i, t}$ and $y_{j, t}$ are domestic and foreign GDP per capita, respectively (source: World Bank, World Development Indicators (WDI) database). ${ }^{10}$ Partner countries' weights $\left(\omega_{j, t}\right)$ are the same as those used in the construction of $R E E R_{i, t}$, see Equation (5). The variable $B S_{i, t}$ is expressed as an index $(100=2000)$ and then converted into logarithms such that $b s_{i, t}=\ln \left(B S_{i, t}\right)$. The terms of trade, tot $t_{i t}$, are defined as the ratio of the country's export price index to its import price index (source: CEPAL). Terms of trade are in logarithms, and expressed as an index $(100=2000)$. Openness $\left(\right.$ open $\left._{i, t}\right)$ is the ratio of imports plus exports to GDP, all these variables being in U.S. dollars (source: WDI). For government spending, $g_{i, t}$, we take the share of government consumption in GDP extracted from WDI.

Turning to the variables involved in misalignments' regressions, we consider the following controls: (i) an indicator of financial development constructed as the ratio of private credit by deposit money banks and other financial institutions to nominal GDP (source: World Bank, Global Financial Development (GFD) database); (ii) a

\footnotetext{
${ }^{10}$ This measure of the Balassa-Samuelson effect is commonly used in the international macroeconomics literature, see Gnimassoun and Mignon $(2015,2016)$ for example. Recently, Couharde, Delatte, Grekou, Mignon, and Morvillier (2020) present and discuss the implications of alternative measures of the Balassa-Samuelson effect suggested in the literature.
} 
banking crisis dummy which takes the value of 1 in the event of a banking crisis and 0 otherwise (source: GFD); (iii) a measure of quality of institutions which consists in a score coding the authority characteristics of states, ranging from +10 (strongly democratic) to -10 (strongly autocratic). This variable is extracted from the Polity IV Project database.

\section{Results}

\subsection{Baseline results}

In this section, we present the results prior to the estimation of exchange rate misalignments. Since the BEER approach relies on a cointegrating relationship, panel unit root and cointegration tests are required. Due to economic and financial globalization, the effects of neighborliness, the impacts of imitation, as well as common shocks that affect the countries, we have to account for cross-sectional dependence when implementing the tests. To avoid any bias related to the omission of potential inter-country dependencies, we perform the test of weak cross-sectional dependence developed by Pesaran (2015) on each variable included in Equation (2) as well as on the residuals of the relation that binds them. The results presented in Table A-2 (Appendix A) reject the null hypothesis and thus confirm the existence of strong inter-country dependence. ${ }^{11}$

To account for this property, we use the CADF test developed by Pesaran (2007) to test the unit root null hypothesis in a heterogeneous panel in the presence of cross-sectional dependence. As shown in Table A-3, the unit root null hypothesis cannot be rejected for all variables, except for the terms of trade (tot) which are thus excluded from the cointegrating relationship. ${ }^{12}$

Turning to cointegration, we rely on Westerlund (2007) to test the null hypothesis of no cointegration based on the estimation of a panel error correction model. Roughly speaking, four tests are proposed by Westerlund, two of which $\left(P_{\tau}\right.$ and $\left.P_{\alpha}\right)$ assume homogeneity of the cointegrating vector (error correction term), the two others $\left(G_{\tau}\right.$

\footnotetext{
${ }^{11}$ Given the long time dimension of our panel and as a robustness check, we also perform the Lagrange multiplier (LM) test developed by Breusch and Pagan (1980) and implemented by Baum (2001) to test for cross-sectional independence. We obtain results that are consistent with those of Pesaran (2015)'s test, strongly rejecting the hypothesis of absence of inter-country dependency.

${ }^{12}$ Note that due to the fairly long time dimension of our panel, we also perform the unit root tests with structural breaks of Lluís Carrion-i Silvestre, Del Barrio-Castro, and López-Bazo (2005). We obtain similar results (available upon request from the authors), illustrating the robustness of our findings.
} 
and $G_{\alpha}$ ) allowing for heterogeneity. As shown in Table A-4, the null hypothesis of no cointegration is rejected when we allow for heterogeneity of the cointegrating vector. Given that homogeneity of the cointegration vector under the alternative hypothesis is quite unlikely in our panel, we therefore conclude in favor of a cointegrating relationship between the real effective exchange rate and its fundamentals in Latin American countries.

The last step of the BEER approach is to estimate the long-term relationship. To this end, we rely on the Dynamic OLS approach (DOLS) proposed by Mark and Sul (2003). In particular, we use a complete specification that allows us to control for cross-sectional dependence:

$$
\operatorname{reer}_{i, t}=\vartheta_{i}+\lambda_{i} t+\theta_{t}+\gamma^{\prime} x_{i, t}+\sum_{s=-p_{i}}^{p_{i}} \delta_{i, s} \Delta x_{i, t-s}+v_{i, t}
$$

where $\vartheta_{i}$ captures individual heterogeneity, $\lambda_{i} t$ takes into account heterogeneous trends, and $\theta_{t}$ controls for common temporal effects (cross-sectional dependence). The fundamentals $(x)$ included in the cointegrating relationship are relative productivity, public expenditure, net foreign assets, and trade openness. Individual lags $\left(-p_{i}\right)$ and individual leads $\left(p_{i}\right)$ of changes in the explanatory variables are introduced to correct possible serial correlation biases. The estimation results with $p=1$ are given by:

$$
\widehat{\operatorname{reer}}_{i, t}=\widehat{\vartheta}_{i}+\underset{[0.169]}{0.2965} b_{i, t}-\underset{[0.002]}{0.0093 \text { open }_{i, t}}+\underset{[0.011]}{0.0238} \text { gov }_{i, t}+\underset{[0.001]}{0.0023} n f a_{i, t} .
$$

where robust standard errors of the estimated coefficients are given in brackets (the full results for $p=1$ and $p=2$ are reported in Table A-5). ${ }^{13}$ The results are consistent with expectations. Indeed, an improvement in net foreign assets, public expenditures, and relative productivity leads to an appreciation of the real exchange rate, while increased trade openness is associated with a real depreciation of the currency. Although there is theoretical ambiguity regarding the sign of the coefficient associated with trade openness, several empirical studies point to a negative relationship (see, e.g., Dubas, 2009; Ibrahim A. Elbadawi and Soto, 2012). Finally, we compute the value of the equilibrium real exchange rates $\left(\widehat{r e e r}_{i, t}\right)$ from these estimation results by considering the long-term components of the exchange rate fundamentals. ${ }^{14}$

\footnotetext{
${ }^{13}$ Consistent with the cointegration test, we introduce one lag and one lead in the relationship for all countries. As shown, the estimated coefficients do not change significantly when these numbers are both increased to two.

${ }^{14}$ Following Schrø̈der (2013) and Comunale (2017), we extract the trend components of the variables using the Hodrick-Prescott filter, with a smoothing parameter of conventional value
} 


\subsection{Size of currency misalignments and ERR}

Table 1 reports the estimated effect of the ERR on the size of currency misalignments (Equation (3)), the regressions being performed with and without time fixed effects. Given the nature of the dependent variable (absolute value of misalignments), we do not introduce country fixed effects in the regressions since this is equivalent to removing the individual averages of the raw variables. Indeed, such a transformation is not relevant from an economic viewpoint in an analysis like ours, whose purpose is to explain the size (distance to zero) of currency misalignments. ${ }^{15}$ Columns (1) to (8) show the results of the overall impact of the ERR, distinguishing the classification of SHA from that of IRR. The last four columns (9)-(12) report the specific impact of the ERR (fixed, intermediate, flexible) based on the IRR classification. In these specifications, each ERR is a dummy variable taking the value 1 for the specified regime and 0 otherwise. For reasons of multicollinearity, only intermediate and flexible regimes are included in the regressions, the fixed regime acting as the benchmark.

Regarding the overall effect of the ERR, the results indicate that greater flexibility is significantly associated with an increase in the size of currency misalignments regardless of the classification, with or without control variables. When time dummies and control variables are included in the regressions (columns (4) and (8)), the estimated ERR coefficient is highly significant whatever the specification, amounting to 0.054 for the SHA classification and 0.076 for the IRR classification. The central result here is that regimes in which the exchange rate is actively pegged produce lower misalignments in absolute terms than do floating regimes, with a difference of around 6 percent. The findings are confirmed by those on the specific effect of the ERR. Indeed, taking the fixed regime as a benchmark in the regression, the results show that countries with a flexible ERR experience significantly higher exchange rate misalignments. ${ }^{16}$ For the sake of completeness, we have estimated two auxiliary regressions to assess whether the monetary and/or budgetary disciplines

$\lambda=100$. Note that, for the sake of completeness and as a robustness check, we also considered the actual values of the exchange rate fundamentals when computing equilibrium exchange rate values. The results (available upon request from the authors) were identical to those reported in the paper.

${ }^{15}$ Formally, allowing for country fixed effects in Equation (3) implicitly defines the dependent variable as $\left|m i s_{i, t}\right|-(1 / T) \sum_{t=1}^{T}\left|m i s_{i, t}\right|$. By construction, such a within transformation allows the left-hand side variable of Equation (3) to take either positive or negative values, which is in contradiction with our goal to assess the effect of the EER on the magnitude of misalignments.

${ }^{16}$ The descriptive statistics reported in Table A-1 in the Appendix A are consistent with these results. The mean and variance of the misalignments (in absolute value terms) are much greater under flexible ERR than under fixed and intermediate regimes, regardless of the classification. 
matter in explaining why fixed ERR are associated with smaller misalignments. ${ }^{17}$ In Table A-6, the dependent variable is the inflation rate, whereas it is the fiscal balance in Table A-7. As shown, fixed ERR are characterized by greater monetary discipline as flexible ERR lead to significantly higher inflation rates. Similarly, fixed ERR outperform flexible regimes in terms of budgetary discipline. Overall, fixed ERR tend to reduce inflation and deficits, a feature that could explain why they perform better in limiting the size of misalignments.

However, we do not observe significant differences in the magnitude of misalignments between countries under intermediate ERR and those with fixed exchange rates. Our results diverge from those of Dubas (2009), who finds that for developing countries, the intermediate ERR is more effective in limiting the size of currency misalignments. ${ }^{18}$ They also differ from those of Gnimassoun (2015), according to which flexible ERR perform well in reducing the magnitude of external imbalances in sub-Saharan African countries. Beyond the difference between the samples used in the studies, the economic stakes of the choice of ERR are not necessarily the same according to the region and the economy. Indeed, major changes have been observed in the choices of ERR in Latin American countries since the end of the Bretton Woods system, with a more pronounced tendency towards flexible or intermediate arrangements since the beginning of the 1990s. This implies a movement toward domestic ERR more consistent with the new international monetary regime that is based on the flotation of the main global currencies (Carrera and Vuletin, 2013).

When they are significantly different from zero at the standard levels, the coefficients associated with the control variables have the expected signs. Indeed, financial development contributes to limiting the size of misalignments, whatever the specification. This result is in line with Devereux and Lane (2003), who show that domestic financial development helps stabilize the exchange rate in developing countries by facilitating intertemporal smoothing by households and firms. Dubas (2009) also highlights a significant contribution of financial development in reducing the size of currency misalignments. Moreover, as expected, the years of banking crises are associated with large significant misalignments. Finally, despite some heterogeneity across the specifications, countries with stronger political institutions (more democratic economies) generally tend to limit the size of currency misalignments.

\footnotetext{
${ }^{17}$ See Appendix B for a detailed presentation of the monetary and budgetary discipline hypotheses.

${ }^{18}$ It is worth mentioning that our article differs from Dubas (2009) in that it uses de facto rather than de jure ERR classifications to test the impact of the ERR on real exchange rate misalignments. Indeed, de facto codings seem to reflect countries' behavior more accurately and, thus, are more appropriate for assessing the effective impact of exchange rate policy on economic variables.
} 
Table 1: Explaining the absolute value of misalignments

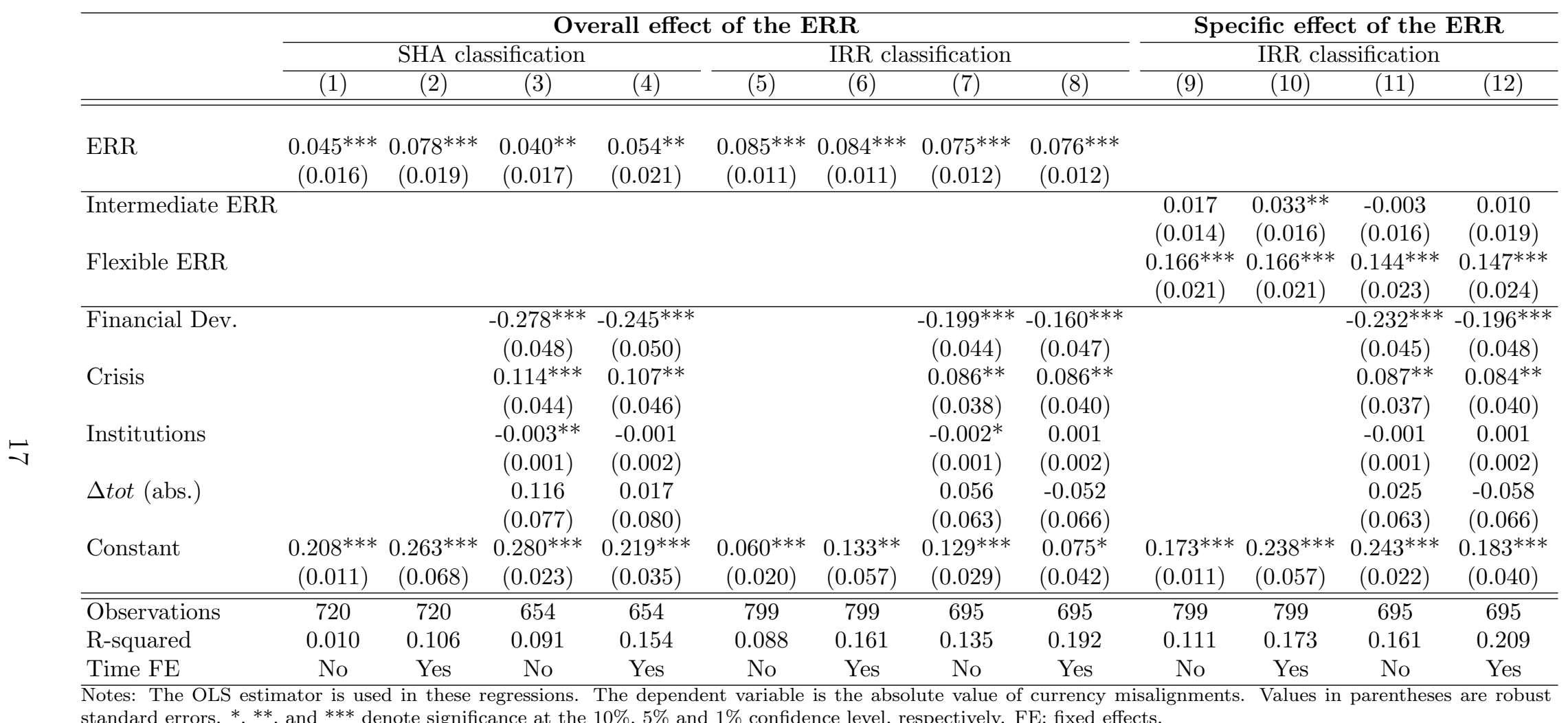




\subsection{Persistence of currency misalignments and ERR}

Let us now assess the impact of ERR on the persistence of currency misalignments. The corresponding results are reported in Table 2, and deserve several comments. First, currency misalignments are characterized by a relatively high level of persistence. Indeed, the lagged misalignment coefficient is highly significant, amounting to 0.663 with the SHA classification (column (1)) and to 0.661 with the IRR classification (column (6)). Consistent with the cointegration hypothesis which implies that misalignments follow a stationary process, these coefficients are significantly less than one. The coefficient $\left(\beta_{2}\right)$ associated with the ERR variable is negative and highly significant with an estimated value equal to -0.136 (-0.084 resp.) in column (1) ((6) resp.). It is worth mentioning that since currency misalignments are not considered in absolute terms in these regressions, the negative signs associated with the ERR cannot be interpreted as a decrease in the size of misalignments thanks to the flexibility of the regime. On the contrary, these negative and significant coefficients, regardless of the classification, probably indicate a tendency for flexible ERR to generate more undervaluations.

Second, the sign of the coefficient associated with the interaction term gives an indication of the impact of the ERR on the persistence of misalignments. Since a higher value of ERR indicates greater flexibility and given that the misalignments are positively and significantly related to their past values, the negative sign associated with the interaction term means that the flexibility of ERR contributes to reducing the persistence of currency misalignments. This result is robust to the classification since the coefficient of the interaction term is negative and significant at the $5 \%$ level under the IRR classification, and significant at the $1 \%$ level under the SHA classification. Columns (5) and (10) report our privileged specifications, as they include both country fixed effects and time dummies. From their estimation, we can derive the degree of persistence of misalignments in each ERR, given by $\hat{\beta}_{1}+$ $\hat{\beta}_{3} \times E R R$. Considering the SHA classification (in which $E R R=0$ if peg and 1 otherwise), the level of persistence in misalignments is 0.848 when the countries are under a fixed ERR and 0.620 when they are not. When we rely on the IRR classification (column (10)), the degree of persistence of currency misalignments is estimated at 0.894 under fixed regimes, 0.739 under intermediate regimes, and 0.584 under floating ERR. Our findings are robust to the retained specification since they remain valid whether country and/or time fixed effects are present or not. Turning to the control variables, they become non-significant-with the exception of the terms of trade - when the lagged values of misalignments are included among the regressors.

Overall, our results show that misalignments are strongly persistent in Latin Amer- 
ican countries. They indicate that more flexibility of ERR reduces this persistence, and thus favors a faster adjustment of currency imbalances. These findings are consistent with Friedman's thesis on the ability of exchange rate flexibility to absorb the economic disequilibria induced by external shocks faster. Although the empirical robustness of this thesis has been questioned by some authors (Berka, Devereux, and Engel, 2012; Chinn and Wei, 2013), it finds a favorable echo in several other studies such as Edwards (2004), Gnimassoun and Mignon (2015), Gervais, Schembri, and Suchanek (2016), Martin (2016), and Ghosh, Qureshi, and Tsangarides (2018).

Finally, the analysis of the impact of the ERR on both the size and persistence of currency misalignments does not allow us to conclude in favor of a privileged ERR. The main conclusion is that there is no panacea for exchange rate policy. Fixed ERR have the advantage of limiting the size of currency imbalances, but they are associated with higher persistence of misalignments. On the contrary, although flexible ERR allow faster absorption of currency imbalances, they are likely to induce larger disequilibria. The choice of ERR is a matter of arbitration. At all events, when a country chooses a fixed ERR, its main challenge is to control its currency misalignments to avoid a significant adjustment cost. 
Table 2: Explaining the persistence of misalignments

\begin{tabular}{|c|c|c|c|c|c|c|c|c|c|c|}
\hline & \multicolumn{5}{|c|}{ SHA classification } & \multicolumn{5}{|c|}{ IRR classification } \\
\hline & $(1)$ & $(2)$ & $(3)$ & $(4)$ & $(5)$ & $(6)$ & $(7)$ & $(8)$ & $(9)$ & $(10)$ \\
\hline Lagged Misalignments $\left(m i s_{i, t-1}\right)$ & $\begin{array}{c}0.663^{* * *} \\
(0.058)\end{array}$ & $\begin{array}{c}0.876^{* * *} \\
(0.079)\end{array}$ & $\begin{array}{c}0.869 * * * \\
(0.089)\end{array}$ & $\begin{array}{c}0.870 * * * \\
(0.079)\end{array}$ & $\begin{array}{c}0.848^{* * *} \\
(0.088)\end{array}$ & $\begin{array}{c}0.661^{* * *} \\
(0.056)\end{array}$ & $\begin{array}{c}1.094^{* * *} \\
(0.105)\end{array}$ & $\begin{array}{c}1.049 * * * \\
(0.114)\end{array}$ & $\begin{array}{c}1.082^{* * *} \\
(0.108)\end{array}$ & $\begin{array}{c}1.049 * * * \\
(0.120)\end{array}$ \\
\hline$E R R_{i, t}$ & $\begin{array}{c}-0.136^{* * *} \\
(0.034)\end{array}$ & $\begin{array}{c}-0.047^{* * *} \\
(0.015)\end{array}$ & $\begin{array}{c}-0.075^{* * *} \\
(0.020)\end{array}$ & $\begin{array}{c}-0.067^{* * *} \\
(0.021)\end{array}$ & $\begin{array}{c}-0.112^{* * *} \\
(0.028)\end{array}$ & $\begin{array}{c}-0.084^{* * *} \\
(0.020)\end{array}$ & $\begin{array}{c}-0.045^{* * *} \\
(0.012)\end{array}$ & $\begin{array}{c}-0.080^{* * *} \\
(0.017)\end{array}$ & $\begin{array}{c}-0.044^{* * *} \\
(0.013)\end{array}$ & $\begin{array}{c}-0.075^{* * *} \\
(0.020)\end{array}$ \\
\hline Interaction $\left(m i s_{i, t-1} \times E R R_{i, t}\right)$ & & $\begin{array}{c}-0.236^{* *} \\
(0.101)\end{array}$ & $\begin{array}{c}-0.242^{* *} \\
(0.112)\end{array}$ & $\begin{array}{c}-0.236^{* *} \\
(0.101)\end{array}$ & $\begin{array}{c}-0.228^{* *} \\
(0.110)\end{array}$ & & $\begin{array}{c}-0.165^{* * *} \\
(0.053)\end{array}$ & $\begin{array}{c}-0.156^{* * *} \\
(0.055)\end{array}$ & $\begin{array}{c}-0.160^{* * *} \\
(0.054)\end{array}$ & $\begin{array}{c}-0.155^{* * *} \\
(0.058) \\
\end{array}$ \\
\hline Financial dev. & $\begin{array}{c}-0.089 \\
(0.123)\end{array}$ & $\begin{array}{c}0.009 \\
(0.052)\end{array}$ & $\begin{array}{c}0.082 \\
(0.121)\end{array}$ & $\begin{array}{l}-0.063 \\
(0.049)\end{array}$ & $\begin{array}{c}-0.055 \\
(0.122)\end{array}$ & $\begin{array}{c}-0.084 \\
(0.121)\end{array}$ & $\begin{array}{l}-0.018 \\
(0.047)\end{array}$ & $\begin{array}{c}0.014 \\
(0.110)\end{array}$ & $\begin{array}{l}-0.065 \\
(0.046)\end{array}$ & $\begin{array}{l}-0.072 \\
(0.118)\end{array}$ \\
\hline Crisis & $\begin{array}{l}-0.006 \\
(0.053)\end{array}$ & $\begin{array}{l}-0.005 \\
(0.051)\end{array}$ & $\begin{array}{l}-0.003 \\
(0.050)\end{array}$ & $\begin{array}{c}0.003 \\
(0.052)\end{array}$ & $\begin{array}{l}-0.003 \\
(0.052)\end{array}$ & $\begin{array}{l}-0.007 \\
(0.046)\end{array}$ & $\begin{array}{l}-0.007 \\
(0.044)\end{array}$ & $\begin{array}{c}-0.006 \\
(0.043)\end{array}$ & $\begin{array}{c}-0.002 \\
(0.046)\end{array}$ & $\begin{array}{l}-0.007 \\
(0.046)\end{array}$ \\
\hline Institutions & $\begin{array}{c}-0.003 \\
(0.003)\end{array}$ & $\begin{array}{c}0.001 \\
(0.002)\end{array}$ & $\begin{array}{c}0.001 \\
(0.002)\end{array}$ & $\begin{array}{c}-0.002 \\
(0.002)\end{array}$ & $\begin{array}{c}-0.004 \\
(0.003)\end{array}$ & $\begin{array}{c}-0.003 \\
(0.003)\end{array}$ & $\begin{array}{l}-0.000 \\
(0.002)\end{array}$ & $\begin{array}{c}0.001 \\
(0.002)\end{array}$ & $\begin{array}{l}-0.003 \\
(0.002)\end{array}$ & $\begin{array}{l}-0.003 \\
(0.003)\end{array}$ \\
\hline Terms of trade & $\begin{array}{c}0.100^{* *} \\
(0.046)\end{array}$ & $\begin{array}{c}0.038 \\
(0.036)\end{array}$ & $\begin{array}{c}0.094^{* *} \\
(0.046)\end{array}$ & $\begin{array}{c}0.025 \\
(0.036)\end{array}$ & $\begin{array}{l}0.085^{*} \\
(0.046)\end{array}$ & $\begin{array}{c}0.139^{* * *} \\
(0.045)\end{array}$ & $\begin{array}{l}0.058^{*} \\
(0.031)\end{array}$ & $\begin{array}{c}0.136^{* * *} \\
(0.044)\end{array}$ & $\begin{array}{l}0.055^{*} \\
(0.030)\end{array}$ & $\begin{array}{c}0.129^{* * *} \\
(0.045)\end{array}$ \\
\hline Constant & $\begin{array}{c}-0.086 \\
(0.089) \\
\end{array}$ & $\begin{array}{l}-0.020 \\
(0.045) \\
\end{array}$ & $\begin{array}{l}-0.084 \\
(0.078) \\
\end{array}$ & $\begin{array}{c}-0.050 \\
(0.069) \\
\end{array}$ & $\begin{array}{l}-0.126 \\
(0.089) \\
\end{array}$ & $\begin{array}{c}0.024 \\
(0.081) \\
\end{array}$ & $\begin{array}{c}0.036 \\
(0.041) \\
\end{array}$ & $\begin{array}{c}0.021 \\
(0.072) \\
\end{array}$ & $\begin{array}{c}0.007 \\
(0.052) \\
\end{array}$ & $\begin{array}{l}-0.015 \\
(0.080) \\
\end{array}$ \\
\hline Observations & $\overline{6654}$ & 654 & $\overline{6654}$ & 654 & $\overline{6654}$ & $\overline{6695}$ & 695 & $\overline{6695}$ & 695 & $\overline{6695}$ \\
\hline R-squared & 0.562 & 0.527 & 0.534 & 0.560 & 0.568 & 0.562 & 0.538 & 0.549 & 0.564 & 0.573 \\
\hline Country FE & Yes & No & Yes & $\mathrm{No}$ & Yes & Yes & $\mathrm{No}$ & Yes & No & Yes \\
\hline Time FE & Yes & No & No & Yes & Yes & Yes & No & No & Yes & Yes \\
\hline
\end{tabular}

Notes: The OLS estimator is used in these regressions. The dependent variable is the estimated value of currency misalignments. Values in parentheses are robust standard errors. ${ }^{*}, *$, and ${ }^{* *}$ denote significance at the $10 \%, 5 \%$ and $1 \%$ confidence level, respectively. FE: fixed effects. 


\section{Robustness checks}

For the sake of completeness, we check the sensitivity of our previous results to the ERR classification, and perform additional robustness tests.

\subsection{On the ERR classification}

In addition to the IRR and SHA classifications, we construct a de facto ERR classification based on the methodology proposed by Coudert and Dubert (2005) (henceforth CD). Although less widely known and used in the literature, Coudert and Dubert (2005)'s method appears to be very precise and well-articulated in the classification criteria. In the Appendix $\mathrm{C}$, we detail the methodology and explain the construction of ERR. Roughly speaking, three steps are involved: (i) detect the presence of a trend in the nominal exchange rate against the U.S. dollar, (ii) compare the volatility of the nominal exchange rate to the volatility for declared floating countries (namely Japan, Great Britain, and Germany, or the Eurozone after 1999 for the latter), and (iii) compare the volatility of international reserves to the volatility for the same bundle of major economies. Based on these three criteria, four types of ERR are distinguished: peg, crawling peg, managed float, pure float. Accordingly, this classification scheme takes four possible values: 1 for peg, 2 for crawling peg, 3 for managed float, and 4 for pure float. This measure covers our 17 countries from 1970 to 2016. During the 1970s, 59 percent of the countries in our sample adopted a pegged regime. This percentage decreased to 32 percent for the period 2010-2016. Thus, the percentage of fixed ERR has declined over time according to the CD classification, as shown in Figure A-1 in the Appendix C. This decreasing pattern is consistent with what we observe when using the SHA and IRR classifications (see Figure 1).

To complement the robustness analysis of our results to the ERR classification, we define a "consensual" peg regime. Like Shambaugh (2004), we consider a binary ERR: peg versus non-peg. The consensus relates to the pegged regime and is reached when, for a given country, the three previous classification schemes (IRR, SHA and CD) are unanimous in indicating a pegged regime in the same year. Note that, as with the recoded classification scheme of Shambaugh, the consensual classification takes the value 0 for the peg scheme, and 1 otherwise. This keeps consistency in the definition of the different classification schemes, from the most rigid to the most flexible, starting from the lowest to the highest value. The correlation coefficient between the consensus classification (henceforth CONS) and the SHA classification is 0.69 for the whole panel, and varies from 0.42 to 1 depending on the country. 
Table 3 is a reproduction of Table 1 with the only difference being that here we use our new classification as well as the consensus classification as variables of interest in the regressions aimed at explaining the size of currency misalignments. The results are consistent and almost identical to our previous findings. As shown, the magnitude of currency misalignments increases with the flexibility of the ERR. These results are significant at conventional levels, with both the CD and CONS classifications, regardless of the specification (with or without time fixed effects). The disaggregated effects of ERR point in the same direction. Indeed, compared to the pegged regime (taken as a benchmark) in the CD classification, the managed floating and pure floating regimes are associated with more substantial currency misalignments. However, the size of currency misalignments under the crawling peg regime does not significantly differ from that under the peg regime. The estimated coefficients of the control variables are also consistent with those of Table 1.

Table 4 reports the results of the regressions related to the effect of the ERR on the persistence of misalignments using the new classification schemes (CD and CONS). The previous findings reported in Table 2 are confirmed and even reinforced. Indeed, the coefficient of the interaction term remains negative and significant at the $1 \%$ level, whatever the classification scheme and the specification (with or without country fixed effects, and with or without time fixed effects). In other words, flexible ERR are more effective in reducing the persistence of currency imbalances, and thus promote a faster adjustment towards the long-run equilibrium exchange rate.

Overall, our results are robust to the ERR classification. They indicate that while flexible ERR are associated with larger currency misalignments, they are the most effective in absorbing them. Likewise, although fixed ERR are associated with less sizeable currency misalignments, they maintain greater persistence. Exchange rate policy in Latin American countries is, therefore, a trade-off issue. The choice of a fixed ERR preserves them from large misalignments, but it is associated with a higher adjustment cost in the event of shocks. When a country chooses a flexible ERR, it faces larger currency misalignments, with potentially disastrous economic consequences, but it can correct them more quickly. This is feasible because the room for maneuver is greater under flexible exchange rates to cope with economic shocks, in particular, external shocks. Changes in the nominal exchange rate affect relative prices and thus contribute to changes in the real exchange rate. Such adjustments are possible in fixed ERR only if the currency pegging rules change (devaluation or revaluation). Since countries are keen to preserve the rules for as long as possible, the currency misalignments that emerge are more persistent. 
Table 3: Sensitivity of the absolute value of misalignments to the choice of the classification

\begin{tabular}{|c|c|c|c|c|c|c|c|c|c|c|c|c|}
\hline & \multicolumn{8}{|c|}{ Overall effect of the ERR } & \multirow{2}{*}{\multicolumn{4}{|c|}{$\begin{array}{c}\text { Specific effect of the ERR } \\
\text { CD classification }\end{array}$}} \\
\hline & \multicolumn{4}{|c|}{ CD classification } & \multicolumn{4}{|c|}{ CONS classification } & & & & \\
\hline & $(1)$ & $(2)$ & $(3)$ & $(4)$ & $(5)$ & $(6)$ & $(7)$ & $(8)$ & $(9)$ & $(10)$ & $(11)$ & $(12)$ \\
\hline ERR & $\begin{array}{c}0.031^{* * *} \\
(0.007)\end{array}$ & $\begin{array}{c}0.042^{* * *} \\
(0.007)\end{array}$ & $\begin{array}{c}0.030^{* * *} \\
(0.007)\end{array}$ & $\begin{array}{c}0.037^{* * *} \\
(0.008) \\
\end{array}$ & $\begin{array}{c}0.070^{* * *} \\
(0.017)\end{array}$ & $\begin{array}{c}0.084^{* * *} \\
(0.019)\end{array}$ & $\begin{array}{c}0.042^{* *} \\
(0.019)\end{array}$ & $\begin{array}{c}0.053^{* *} \\
(0.022) \\
\end{array}$ & & & & \\
\hline Crawling Peg & & & & & & & & & $\begin{array}{c}0.001 \\
(0.016)\end{array}$ & $\begin{array}{c}0.013 \\
(0.019)\end{array}$ & $\begin{array}{l}-0.010 \\
(0.019)\end{array}$ & $\begin{array}{l}-0.006 \\
(0.022)\end{array}$ \\
\hline Managed floating & & & & & & & & & $\begin{array}{c}0.095^{* * *} \\
(0.024)\end{array}$ & $\begin{array}{c}0.099^{* * *} \\
(0.024)\end{array}$ & $\begin{array}{c}0.085^{* * *} \\
(0.026)\end{array}$ & $\begin{array}{c}0.087^{* * *} \\
(0.027)\end{array}$ \\
\hline Pure floating & & & & & & & & & $\begin{array}{c}0.069^{* * *} \\
(0.022)\end{array}$ & $\begin{array}{c}0.109^{* * *} \\
(0.022)\end{array}$ & $\begin{array}{c}0.066^{* * *} \\
(0.024)\end{array}$ & $\begin{array}{c}0.095^{* * *} \\
(0.025)\end{array}$ \\
\hline Financial dev. & & & $\begin{array}{c}-0.251^{* * *} \\
(0.045)\end{array}$ & $\begin{array}{c}-0.209^{* * *} \\
(0.047)\end{array}$ & & & $\begin{array}{c}-0.267^{* * *} \\
(0.051)\end{array}$ & $\begin{array}{c}-0.239^{* * *} \\
(0.054)\end{array}$ & & & $\begin{array}{c}-0.258^{* * *} \\
(0.045)\end{array}$ & $\begin{array}{c}-0.221^{* * *} \\
(0.047)\end{array}$ \\
\hline Crisis & & & $\begin{array}{c}0.099^{* * *} \\
(0.038)\end{array}$ & $\begin{array}{c}0.088^{* *} \\
(0.041)\end{array}$ & & & $\begin{array}{c}0.119^{* * *} \\
(0.044)\end{array}$ & $\begin{array}{c}0.113^{* *} \\
(0.046)\end{array}$ & & & $\begin{array}{c}0.090^{* *} \\
(0.040)\end{array}$ & $\begin{array}{c}0.083^{* *} \\
(0.041)\end{array}$ \\
\hline Institutions & & & $\begin{array}{c}-0.003^{* *} \\
(0.001)\end{array}$ & $\begin{array}{c}-0.001 \\
(0.002)\end{array}$ & & & $\begin{array}{c}-0.003^{*} \\
(0.001)\end{array}$ & $\begin{array}{l}-0.001 \\
(0.002)\end{array}$ & & & $\begin{array}{c}-0.003^{*} \\
(0.001)\end{array}$ & $\begin{array}{l}-0.001 \\
(0.002)\end{array}$ \\
\hline$\Delta$ tot $(a b s)$. & & & $\begin{array}{c}0.059 \\
(0.067)\end{array}$ & $\begin{array}{l}-0.045 \\
(0.070)\end{array}$ & & & $\begin{array}{c}0.102 \\
(0.074)\end{array}$ & $\begin{array}{c}0.006 \\
(0.080)\end{array}$ & & & $\begin{array}{c}0.041 \\
(0.067)\end{array}$ & $\begin{array}{l}-0.051 \\
(0.070)\end{array}$ \\
\hline Constant & $\begin{array}{c}0.163^{* * *} \\
(0.015) \\
\end{array}$ & $\begin{array}{c}0.185^{* * *} \\
(0.071) \\
\end{array}$ & $\begin{array}{c}0.232^{* * *} \\
(0.024) \\
\end{array}$ & $\begin{array}{c}0.141^{* * *} \\
(0.042) \\
\end{array}$ & $\begin{array}{c}0.182^{* * *} \\
(0.013)\end{array}$ & $\begin{array}{c}0.221^{* * *} \\
(0.066)\end{array}$ & $\begin{array}{c}0.268^{* * *} \\
(0.027)\end{array}$ & $\begin{array}{c}0.189^{* * *} \\
(0.040)\end{array}$ & $\begin{array}{c}0.199^{* * *} \\
(0.011)\end{array}$ & $\begin{array}{c}0.230^{* * *} \\
(0.069)\end{array}$ & $\begin{array}{c}0.273^{* * *} \\
(0.021)\end{array}$ & $\begin{array}{c}0.190^{* * *} \\
(0.039)\end{array}$ \\
\hline Observations & 799 & 799 & 695 & 695 & 720 & 720 & 654 & 654 & 799 & 799 & 695 & 695 \\
\hline R-squared & 0.025 & 0.121 & 0.092 & 0.163 & 0.017 & 0.105 & 0.090 & 0.152 & 0.036 & 0.125 & 0.104 & 0.171 \\
\hline Country FE & No & No & No & No & No & No & No & No & No & No & No & No \\
\hline Time FE & No & Yes & No & Yes & No & Yes & No & Yes & No & Yes & No & Yes \\
\hline
\end{tabular}

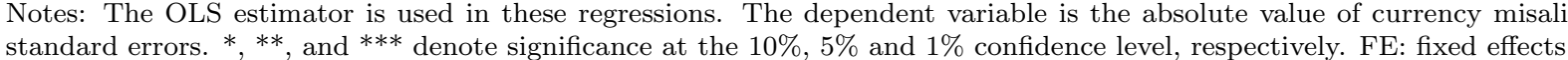


Table 4: Sensitivity of the persistence of misalignments to the choice of the classification

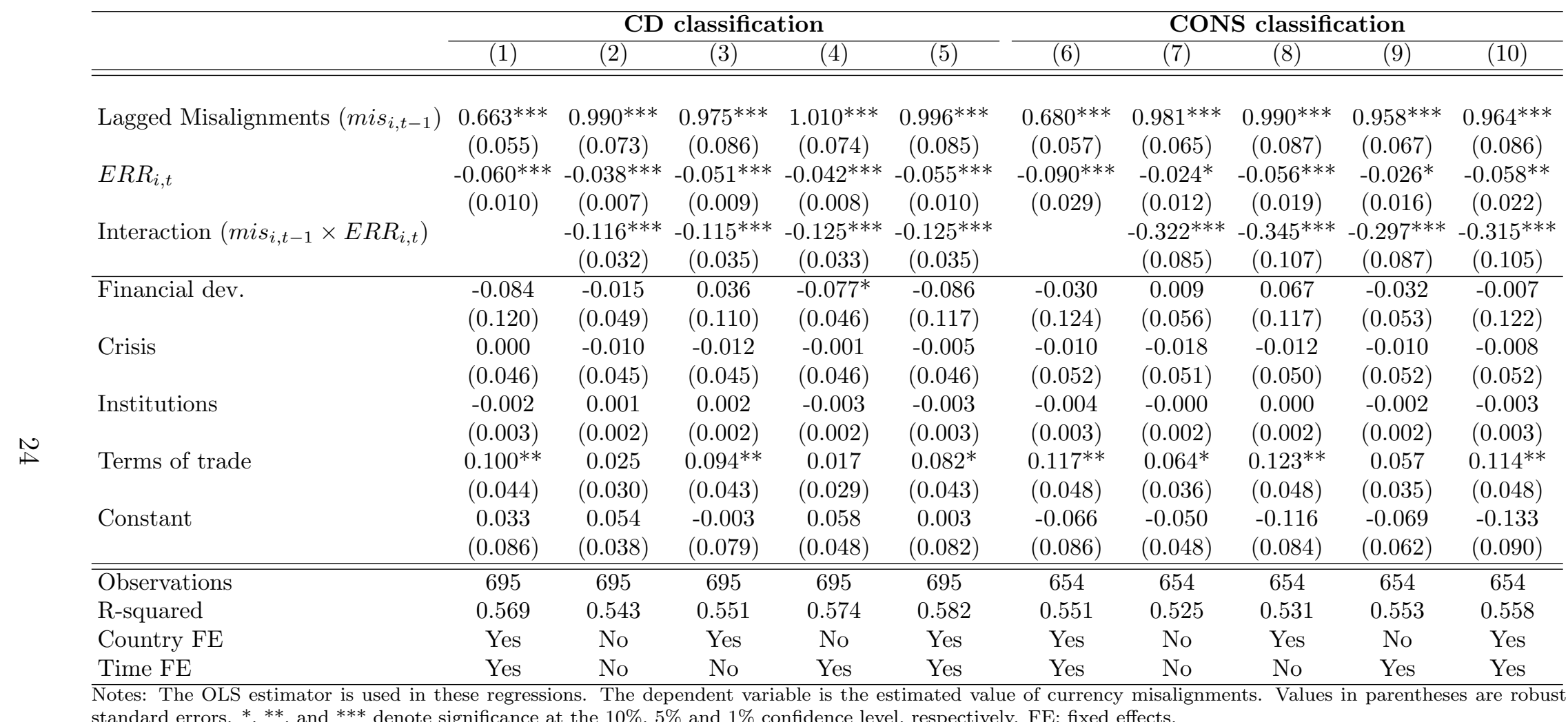




\subsection{Additional robustness tests}

First, we assess the effect of the ERR on the size of misalignments through the prism of regional differences in terms of exchange rate policy. This exercise is not only interesting in its own right but also serves as a robustness test. Indeed, when we focus on the Central American countries, we notice that the frequency of managed or pure floating regimes represents between 12 and $26 \%$ of the total depending on the classification, against 30 to $39 \%$ for the whole panel. In other words, the Central American countries remained for the most part under a peg (50\%) or crawling peg $(23 \%)$ regime over the period under study. Therefore, given the above results, we can expect the size of misalignments to be smaller in this region than in the South American area. To test this hypothesis, we first construct a Central America dummy variable that takes the value of one for the following countries: Costa Rica, Dominican Republic, Guatemala, Honduras, Jamaica, Mexico, Panama, and Trinidad and Tobago, and zero for the other countries. Then, we replace in regression (3) the EER variable with the Central America dummy. Table 5 presents the results. As shown, in each specification, the Central America dummy variable has an associated significantly negative coefficient. These results confirm further that the level of misalignments depends heavily on a country's ERR. 
Table 5: The regional effect of the exchange rate regime

\begin{tabular}{lcccc}
\hline & $(1)$ & $(2)$ & $(3)$ & $(4)$ \\
\hline \hline \multirow{2}{*}{ Central American dummy } & $-0.119^{* * *}$ & $-0.119^{* * *}$ & $-0.118^{* * *}$ & $-0.124^{* * *}$ \\
& $(0.014)$ & $(0.014)$ & $(0.015)$ & $(0.015)$ \\
\hline Financial dev. & & & $-0.256^{* * *}$ & $-0.219^{* * *}$ \\
Crisis & & & $(0.042)$ & $(0.043)$ \\
& & & $0.090^{* *}$ & $0.080^{* *}$ \\
Institutions & & & $(0.037)$ & $(0.040)$ \\
& & & -0.001 & 0.002 \\
$\Delta$ tot(abs.) & & & $(0.001)$ & $(0.002)$ \\
& & & 0.049 & -0.052 \\
Constant & $0.287^{* * *}$ & $0.317^{* * *}$ & $0.346^{* * * *}$ & $0.283^{* * *}$ \\
& $(0.012)$ & $(0.063)$ & $(0.021)$ & $(0.036)$ \\
\hline \hline Observations & 799 & 799 & 695 & 695 \\
R-squared & 0.074 & 0.155 & 0.140 & 0.208 \\
Country FE & No & No & No & No \\
Time FE & No & Yes & No & Yes
\end{tabular}

Notes: The OLS estimator is used in these regressions. The dependent variable is the absolute value of currency misalignments. The dummy variable of Central America takes the value 1 when the country belongs to Central America and 0 otherwise. Values in parentheses are robust standard errors. *, **, and $* * *$ denote significance at the $10 \%, 5 \%$ and $1 \%$ confidence level, respectively. FE: fixed effects.

Second, instead of the absolute value of misalignments, we consider squared misalignments as a measure of size. This is obviously a way to exaggerate the size of misalignments, and to examine whether the ERR has an impact on increasingly large currency distortions. As shown in Table 6, flexible ERR are associated with increasingly extreme misalignments regardless of classification - the effect being less significant (10\%) with the SHA and CONS classifications. It is also worth mentioning that financial development appears to be an absorber of extreme misalignments. 
Table 6: Squared misalignments

\begin{tabular}{|c|c|c|c|c|c|c|c|c|}
\hline & \multicolumn{2}{|c|}{ SHA classification } & \multicolumn{2}{|c|}{ IRR classification } & \multicolumn{2}{|c|}{ CD classification } & \multicolumn{2}{|c|}{ CONS classification } \\
\hline & (1) & (2) & $(3)$ & (4) & (5) & (6) & (7) & (8) \\
\hline ERR & $\begin{array}{c}0.029 * \\
(0.016)\end{array}$ & $\begin{array}{l}0.034^{*} \\
(0.019)\end{array}$ & $\begin{array}{c}0.066^{* * *} \\
(0.012)\end{array}$ & $\begin{array}{c}0.064^{* * *} \\
(0.012)\end{array}$ & $\begin{array}{c}0.025^{* * *} \\
(0.007)\end{array}$ & $\begin{array}{c}0.032^{* * *} \\
(0.008)\end{array}$ & $\begin{array}{c}0.029^{*} \\
(0.016)\end{array}$ & $\begin{array}{l}0.034^{*} \\
(0.019)\end{array}$ \\
\hline Financial dev. & $\begin{array}{c}-0.203^{* * *} \\
(0.049)\end{array}$ & $\begin{array}{c}-0.167^{* * *} \\
(0.051)\end{array}$ & $\begin{array}{c}-0.135^{* * * *} \\
(0.041)\end{array}$ & $\begin{array}{c}-0.091^{* *} \\
(0.043)\end{array}$ & $\begin{array}{c}-0.182^{* * * *} \\
(0.043)\end{array}$ & $\begin{array}{c}-0.132^{* * *} \\
(0.044)\end{array}$ & $\begin{array}{c}-0.203^{* * *} \\
(0.049)\end{array}$ & $\begin{array}{c}-0.167^{* * * *} \\
(0.051)\end{array}$ \\
\hline Crisis & $\begin{array}{c}0.139^{* *} \\
(0.057)\end{array}$ & $\begin{array}{c}0.128^{* *} \\
(0.058)\end{array}$ & $\begin{array}{c}0.102^{* *} \\
(0.048)\end{array}$ & $\begin{array}{l}0.100^{*} \\
(0.051)\end{array}$ & $\begin{array}{c}0.114^{* *} \\
(0.049)\end{array}$ & $\begin{array}{c}0.101^{* *} \\
(0.051)\end{array}$ & $\begin{array}{c}0.139^{* *} \\
(0.057)\end{array}$ & $\begin{array}{c}0.128^{* *} \\
(0.058)\end{array}$ \\
\hline Institution & $\begin{array}{l}-0.001 \\
(0.001)\end{array}$ & $\begin{array}{l}-0.000 \\
(0.002)\end{array}$ & $\begin{array}{l}-0.001 \\
(0.001)\end{array}$ & $\begin{array}{c}0.001 \\
(0.002)\end{array}$ & $\begin{array}{l}-0.002 \\
(0.001)\end{array}$ & $\begin{array}{l}-0.001 \\
(0.002)\end{array}$ & $\begin{array}{l}-0.001 \\
(0.001)\end{array}$ & $\begin{array}{l}-0.000 \\
(0.002)\end{array}$ \\
\hline$\Delta$ tot (abs.) & $\begin{array}{c}0.041 \\
(0.060)\end{array}$ & $\begin{array}{c}-0.048 \\
(0.070)\end{array}$ & $\begin{array}{c}0.012 \\
(0.050)\end{array}$ & $\begin{array}{c}-0.076 \\
(0.060)\end{array}$ & $\begin{array}{c}0.014 \\
(0.052)\end{array}$ & $\begin{array}{c}-0.070 \\
(0.061)\end{array}$ & $\begin{array}{c}0.041 \\
(0.060)\end{array}$ & $\begin{array}{c}-0.048 \\
(0.070)\end{array}$ \\
\hline Constant & $\begin{array}{c}0.129^{* * *} * \\
(0.023)\end{array}$ & $\begin{array}{c}0.058^{* *} \\
(0.025)\end{array}$ & $\begin{array}{l}-0.000 \\
(0.026)\end{array}$ & $\begin{array}{l}-0.047 \\
(0.029)\end{array}$ & $\begin{array}{c}0.093^{* * *} \\
(0.021)\end{array}$ & $\begin{array}{c}0.008 \\
(0.027)\end{array}$ & $\begin{array}{c}0.129^{* * *} \\
(0.023)\end{array}$ & $\begin{array}{c}0.058^{* *} \\
(0.025)\end{array}$ \\
\hline$\overline{\overline{\text { Observations }}}$ & 654 & 654 & 695 & $\overline{695}$ & $\overline{695}$ & $\overline{695}$ & 2654 & 654 \\
\hline R-squared & 0.063 & 0.138 & 0.098 & 0.164 & 0.065 & 0.145 & 0.063 & 0.138 \\
\hline Time FE & No & Yes & No & Yes & No & Yes & No & Yes \\
\hline
\end{tabular}

Finally, turning to methodological issues and as an ultimate robustness test, instead of using the DOLS estimator, we rely on the Dynamic Common-Correlated Effects (DCCE) estimator developed by Chudik and Pesaran (2015). This estimator is specially designed to account for cross-section dependence, and is therefore particularly relevant in our case. We compute a new series of currency misalignments using this estimator, and subsequently estimate all the previously considered regressions on the size and persistence of misalignments with all the classifications. We obtain the same results, and our main conclusions remain unchanged. ${ }^{19}$

\section{Conclusion}

This paper aims at assessing the impact of ERR on currency misalignments in Latin American countries. We investigate whether the choice of ERR affects both the size and the persistence of exchange rate imbalances.

Relying on a panel of 17 Latin American countries over the 1970-2016 period, we

\footnotetext{
${ }^{19}$ To save space, we do not report the results, but they are available upon request from the authors.
} 
show that greater flexibility in the ERR is associated with larger currency misalignments compared to a fixed regime. Complementarily, our findings show that, whereas misalignments are found to be persistent, such inertia is lower under flexible regimes. In other words, floating ERR permit a faster correction of currency imbalances in line with Friedman's hypothesis. Thanks to flexibility, changes in the nominal exchange rate have an impact on relative prices and, thus, on the real exchange rate allowing countries under flexible ERR to react more quickly when they face external shocks. Nevertheless, as a compensation to this limitation to adjust shocks and correct misalignments, fixed ERR show more monetary and budgetary disciplines which as we find that fixed ERR tend to reduce inflation and deficits.

On the whole, our paper shows that Latin American countries face a key trade-off in their choice of ERR: they have to arbitrate between sizeable but less persistent misalignments on the one hand, and long-lasting but lower currency imbalances on the other hand. Given their history, Latin American countries should pay particular attention to their exchange rate policies, and have to adopt policies that govern the behavior of the real exchange rate. Indeed, as discussed in Frenkel and Rapetti (2010) and Martin Guzman and Stiglitz (2018), preserving a stable and competitive real exchange rate appears to be the necessary condition to sustain economic growth in the region. Exchange rate policy has a key role to play in achieving this goal. 


\section{A Descriptive statistics, cross-sectional indepen- dence, unit root and cointegration tests results}

Table A-1: Descriptive statistics

\begin{tabular}{l|ccccc}
\hline Variables & Obs. & Mean & S.D. & Min. & Max. \\
\hline \hline Relative productivity (BS measure) & 799 & 112.285 & 25.541 & 56.298 & 198.255 \\
Real effective exchange rate (REER) & 799 & 114.780 & 49.779 & 9.692 & 558.756 \\
Trade openness (X+M, \%GDP) & 799 & 59.146 & 31.534 & 10.337 & 165.344 \\
Government expenditures (\%GDP) & 799 & 12.417 & 3.556 & 3.219 & 22.734 \\
Net foreign assets (\%GDP) & 799 & -44.521 & 36.541 & -220.102 & 11.655 \\
Exchange rate misalignment & 799 & -0.000 & 0.317 & -1.717 & 1.152 \\
Exchange rate misalignment (absolute value) & 799 & 0.231 & 0.217 & 0.000 & 1.717 \\
\cline { 1 - 2 }$\quad$ under fixed regime (IRR) & 221 & 0.173 & 0.159 & 0.001 & 1.018 \\
$\quad$ under intermediate regime (IRR) & 333 & 0.190 & 0.153 & 0.000 & 0.764 \\
$\quad$ under flexible regime (IRR) & 245 & 0.339 & 0.288 & 0.005 & 1.717 \\
$\quad$ under pegged regime (SHA) & 270 & 0.208 & 0.182 & 0.001 & 1.152 \\
$\quad$ under non pegged regime (SHA) & 450 & 0.253 & 0.242 & 0.000 & 1.717 \\
Financial development & 797 & 0.281 & 0.172 & 0.026 & 1.086 \\
Crisis & 714 & 0.104 & 0.305 & 0.000 & 1.000 \\
Quality of institutions & 799 & 4.995 & 5.937 & -9.000 & 10.000 \\
Terms of trade (tot) & 799 & 94.679 & 26.426 & 23.212 & 220.593 \\
Atot (abs.) & 782 & 0.080 & 0.098 & 0.000 & 1.078 \\
GDP pc growth & 799 & 1.824 & 3.966 & -15.219 & 16.129 \\
Election year & 799 & 0.260 & 0.439 & 0.000 & 1.000 \\
\hline
\end{tabular}

Table A-2: Testing weak (no) cross-sectional dependence

\begin{tabular}{l|c|c|c}
\hline Variables & Test name & Test statistics & P-value \\
\hline \hline reer & Pesaran WCD test & 79.523 & 0.000 \\
bs & Pesaran WCD test & 79.852 & 0.000 \\
gov & Pesaran WCD test & 77.106 & 0.000 \\
open & Pesaran WCD test & 77.231 & 0.000 \\
$n f a$ & Pesaran WCD test & 64.222 & 0.000 \\
tot & Pesaran WCD test & 79.746 & 0.000 \\
$\hat{v}$ & Pesaran WCD test & 6.311 & 0.000 \\
$\hat{v}$ & Breusch-Pagan LM test of CSI & 803.150 & 0.000 \\
\hline
\end{tabular}

Notes: The Pesaran test is performed on the raw variables and the residuals, whereas the Breusch and Pagan test is only a post-estimation test. WCD stands for the null hypothesis of "weak cross-sectional dependence", and CSI for the null hypothesis of "cross-sectional independence". $\hat{v}$ are the estimated residuals from regression (7). 
Table A-3: Results of Pesaran (2007)'s unit root tests

\begin{tabular}{l|c|c|c|c|c}
\hline & CADF t-stat & \multirow{2}{*}{ P-value } & \multicolumn{3}{|c}{ Critical values } \\
\cline { 4 - 6 } & & & $10 \%$ & $5 \%$ & $1 \%$ \\
\hline \hline reer & -1.658 & 0.999 & -2.630 & -2.710 & -2.850 \\
bs & -2.540 & 0.175 & -2.630 & -2.710 & -2.850 \\
gov & -2.286 & 0.599 & -2.630 & -2.710 & -2.850 \\
open & -1.847 & 0.990 & -2.630 & -2.710 & -2.850 \\
tot & -2.872 & 0.006 & -2.630 & -2.710 & -2.850 \\
nfa & -2.111 & 0.859 & -2.630 & -2.710 & -2.850 \\
\hline
\end{tabular}

Table A-4: Results of Westerlund (2007)'s cointegration tests

\begin{tabular}{l|c|c|c}
\hline \hline Statistic & Value & Z-value & Robust P-value \\
\hline$G_{\tau}$ & -3.036 & -0.781 & 0.055 \\
$G_{\alpha}$ & -12.979 & 2.092 & 0.017 \\
$P_{\tau}$ & -11.146 & -0.313 & 0.169 \\
$P_{\alpha}$ & -10.543 & 1.602 & 0.161 \\
\hline
\end{tabular}

Notes: The width of the Bartlett kernel window used in the semiparametric estimation of long-run variances is defined according to the number $4(T / 100)^{2 / 9} \approx 3$. The number of bootstrap replications is 1000 . One lag and one lead have been considered.

Table A-5: Estimation results of the cointegrating relationship

\begin{tabular}{l|c|c}
\hline \multirow{2}{*}{} & \multicolumn{2}{|c}{ Number of lags/leads $(p)$} \\
\cline { 2 - 3 } & $p=1$ & $p=2$ \\
\hline \hline bs & $0.2965^{*}$ & 0.2362 \\
open & $(0.169)$ & $(0.156)$ \\
& $-0.0093^{* * *}$ & $-0.0078^{* * *}$ \\
gov & $(0.002)$ & $(0.001)$ \\
& $0.0238^{* *}$ & $0.0311^{* * *}$ \\
fa & $(0.011)$ & $(0.011)$ \\
& $0.0023^{* * *}$ & $0.0021^{* * *}$ \\
\hline \hline Observations & $(0.001)$ & $(0.001)$ \\
Country FE & 748 & 714 \\
Time FE & Yes & Yes \\
Heterogeneous trends & Yes & Yes \\
\hline
\end{tabular}

Notes: ${ }^{*},{ }^{* *}$, and ${ }^{* * *}$ denote significance at the $10 \%, 5 \%$ and $1 \%$ confidence level, respectively. Values in parentheses are robust standard errors. FE: fixed effects. 


\section{B Monetary and budgetary disciplines}

Our approach to assess whether the monetary and budgetary discipline hypotheses hold consists in testing the impact of the ERR on inflation and fiscal balance. ${ }^{20}$ To this end, we rely on the following specifications:

$$
\begin{aligned}
\pi_{i, t} & =\theta_{0}+\theta_{1} E R R_{i, t}+\sum_{l=1}^{k} \eta_{l} X_{i, t}^{l}+\epsilon_{i, t}, \\
\text { fiscal }_{i, t} & =\delta_{0}+\delta_{1} E R R_{i, t}+\sum_{l=1}^{k} \theta_{l} X_{i, t}^{l}+v_{i, t},
\end{aligned}
$$

where $\pi_{i, t}$ is the inflation rate in country $i$ at time year $t$, and fiscal $l_{i, t}$ is general government net lending/borrowing over GDP in country $i$ at time year $t$. The control variables included in $X_{i, t}$ are the GDP per capita growth rate and the log of terms of trade. In the budgetary regression (9b), we also control for the electoral cycle by adding a dummy variable indicating if, in a specific year, presidential or parliamentary elections have taken place. The sources and data construction of variables involved in Equations (9a) and (9b) are the following. The inflation rate $\pi_{i, t}$ (based on consumer prices) and the GDP per capita growth rate come from the World Bank's World Development Indicators. General government net lending/borrowing, expressed as a percent of GDP ( fiscal $_{i, t}$ ), is taken from the IMF International Financial Statistics database. The terms of trade, $t_{\text {tot }}$, are defined as the ratio of the country's export price index to its import price index (source: CEPAL). Finally, the elections dummy variable takes the value 1 in years in which presidential or parliamentary elections have taken place, 0 otherwise (source: International Institute for Democracy and Electoral Assistance). Note that the fiscal variable covers all countries in our sample but is spotty before 1990, significantly reducing the number of observations. The estimation of Equations (9a) and (9b) is performed using OLS.

Table A-6 reports the estimated effect of the ERR on inflation (Equation (9a)), the regressions being performed with and without country and time fixed effects. ${ }^{21}$ Our primary interest is in the value of $\hat{\theta}_{1}$ which measures the effect of ERR on inflation. The estimates $\hat{\theta}_{1}$ remain highly significant across all the specifications. When using the SHA classification, they vary from a low of 0.042 (column (2)) to a high of 0.162 (column (3)). Moreover, the results, reported in columns (5) to (8), show that our

\footnotetext{
${ }^{20}$ Monetary and fiscal disciplines here refer to the control (reduction) of inflation and the fiscal deficit, respectively. We do not elaborate further on this analysis which is beyond the scope of this paper.

${ }^{21}$ When estimating Equation (9a), we remove observations characterized by $\pi_{i, t}>100 \%$ to ensure that the results are not driven by spurious country/year observations.
} 
estimates of $\hat{\theta}_{1}$ are also positive with the use of the IRR classification. In particular, the estimated coefficient remains highly significant and almost insensitive to the econometric specification in all four cases. Note also that the coefficients associated with the two control variables have the expected signs (although the estimates for the coefficient associated with terms of trade are less precise). By and large, our results reveal that fixed ERR tend to generate significantly less inflation. This in turn supports the monetary discipline hypothesis.

Table A-6: Test of the hypothesis of monetary discipline (Equation (9a))

\begin{tabular}{|c|c|c|c|c|c|c|c|c|}
\hline & \multicolumn{4}{|c|}{ SHA classification } & \multicolumn{4}{|c|}{ IRR classification } \\
\hline & (1) & (2) & (3) & (4) & (5) & (6) & (7) & (8) \\
\hline ERR & $\begin{array}{c}0.098^{* * *} \\
(0.014)\end{array}$ & $\begin{array}{c}0.042^{* * *} \\
(0.013)\end{array}$ & $\begin{array}{c}0.162^{* * *} \\
(0.016)\end{array}$ & $\begin{array}{c}0.113^{* * *} \\
(0.017)\end{array}$ & $\begin{array}{c}0.079^{* * *} \\
(0.010)\end{array}$ & $\begin{array}{c}0.083^{* * *} \\
(0.013)\end{array}$ & $\begin{array}{c}0.091^{* * *} \\
(0.010)\end{array}$ & $\begin{array}{c}0.096^{* * * *} \\
(0.013)\end{array}$ \\
\hline GDP pc growth & $\begin{array}{c}-0.004^{* *} \\
(0.002)\end{array}$ & $\begin{array}{c}-0.005^{* *} \\
(0.002)\end{array}$ & $\begin{array}{l}-0.002 \\
(0.002)\end{array}$ & $\begin{array}{l}-0.003 \\
(0.002)\end{array}$ & $\begin{array}{c}-0.004^{* *} \\
(0.002)\end{array}$ & $\begin{array}{c}-0.004^{* *} \\
(0.002)\end{array}$ & $\begin{array}{c}-0.003^{*} \\
(0.002)\end{array}$ & $\begin{array}{l}-0.002 \\
(0.002)\end{array}$ \\
\hline Terms of trade & $\begin{array}{c}0.076^{* *} \\
(0.038)\end{array}$ & $\begin{array}{c}0.090^{* *} \\
(0.038)\end{array}$ & $\begin{array}{c}0.052 \\
(0.032)\end{array}$ & $\begin{array}{c}0.051 \\
(0.035)\end{array}$ & $\begin{array}{c}0.012 \\
(0.031)\end{array}$ & $\begin{array}{c}0.045 \\
(0.033)\end{array}$ & $\begin{array}{c}-0.011 \\
(0.028)\end{array}$ & $\begin{array}{c}0.012 \\
(0.030)\end{array}$ \\
\hline Constant & $\begin{array}{c}0.025 \\
(0.041)\end{array}$ & $\begin{array}{c}0.034 \\
(0.042)\end{array}$ & $\begin{array}{c}-0.004 \\
(0.040)\end{array}$ & $\begin{array}{c}0.006 \\
(0.043)\end{array}$ & $\begin{array}{c}-0.008 \\
(0.039)\end{array}$ & $\begin{array}{c}-0.075 \\
(0.049)\end{array}$ & $\begin{array}{c}-0.051 \\
(0.041)\end{array}$ & $\begin{array}{c}-0.115^{* *} \\
(0.049)\end{array}$ \\
\hline Observations & 628 & 628 & 628 & 628 & 705 & 705 & 705 & 705 \\
\hline R-squared & 0.086 & 0.220 & 0.404 & 0.491 & 0.132 & 0.263 & 0.397 & 0.518 \\
\hline Country FE & No & Yes & No & Yes & No & Yes & No & Yes \\
\hline Time FE & No & No & Yes & Yes & No & No & Yes & Yes \\
\hline
\end{tabular}

Table A-7 shows the results when investigating the budgetary discipline hypothesis. The baseline specifications (columns (4) and (8)) control for country and time fixed effects. In both cases, the estimated coefficient $\delta_{1}$ is highly significant and ranges from -1.005 (SHA) to -0.942 (IRR). These estimates suggest that a permanent transition to a more flexible ERR regime (from a peg to a non-peg regime in SHA, for instance) is associated with a reduction of the fiscal stance of $1 \%$ of GDP. This is a sizable effect. However, as columns (2), (5) and (7) reveal, this effect is not always statistically significant at conventional confidence levels. The regressions in Table A-7 also control for GDP per capita growth, terms of trade and elections. As expected, positive shocks to GDP per capita growth are favorable for the fiscal balance, while the coefficient for terms of trade is insignificant. Interestingly, the coefficient associated with the election dummy variable is negative and significant in regressions that control for country fixed effects (columns (2), (4), (6) and (8)), whereas this is not the case in otherwise identical regressions that do not account for such effects (columns (1), (3), (5) and (7)). Given the difficulty of controlling for all 
the country-specific determinants of fiscal balance, there are good reasons to distrust estimates from panel regressions that do not include country fixed effects. That is why panel regressions with fixed effects are our preferred specifications when investigating the budgetary discipline hypothesis. Although our findings for the budgetary discipline are less clear-cut than our results on the monetary discipline hypothesis, our preferred specifications in which country and time fixed effects are present (columns (4) and (8)) suggest that fixed ERR tend to weaken deficits. Overall, the budgetary discipline hypothesis is thus corroborated.

Table A-7: Test of the hypothesis of budgetary discipline (Equation (9b))

\begin{tabular}{|c|c|c|c|c|c|c|c|c|}
\hline & \multicolumn{4}{|c|}{ SHA classification } & \multicolumn{4}{|c|}{ IRR classification } \\
\hline & (1) & $(2)$ & $(3)$ & $(4)$ & $(5)$ & (6) & (7) & $(8)$ \\
\hline \multirow[t]{2}{*}{ ERR } & $-0.564^{*}$ & -0.640 & $-0.539^{*}$ & $-1.005^{* *}$ & -0.050 & $-1.179 * * *$ & 0.157 & $-0.942^{* * *}$ \\
\hline & $(0.333)$ & $(0.412)$ & $(0.316)$ & $(0.395)$ & $(0.226)$ & $(0.372)$ & $(0.184)$ & $(0.316)$ \\
\hline \multirow[t]{2}{*}{ GDP pc growth } & $0.409^{* * *}$ & $0.388^{* * *}$ & $0.363^{* * *}$ & $0.324^{* * *}$ & $0.447^{* * *}$ & $0.407^{* * *}$ & $0.406^{* * *}$ & $0.349^{* * *}$ \\
\hline & $(0.052)$ & $(0.048)$ & $(0.049)$ & $(0.047)$ & $(0.051)$ & $(0.047)$ & $(0.048)$ & $(0.048)$ \\
\hline \multirow[t]{2}{*}{ Terms of trade } & -1.694 & -0.824 & -0.772 & $1.941^{*}$ & -1.469 & -0.546 & -0.527 & 1.459 \\
\hline & $(1.131)$ & $(1.544)$ & $(0.890)$ & $(1.159)$ & $(1.046)$ & $(1.238)$ & $(0.831)$ & $(1.037)$ \\
\hline \multirow[t]{2}{*}{ Election year } & -0.489 & $-0.474^{*}$ & -0.444 & $-0.482^{* *}$ & -0.442 & $-0.428^{*}$ & -0.464 & $-0.459^{*}$ \\
\hline & $(0.312)$ & $(0.242)$ & $(0.317)$ & $(0.235)$ & $(0.295)$ & $(0.233)$ & $(0.292)$ & $(0.234)$ \\
\hline \multirow[t]{2}{*}{ Constant } & -0.441 & -0.940 & 1.693 & $-4.895^{* * *}$ & -1.180 & 0.143 & 0.746 & $-3.399 * * *$ \\
\hline & $(1.069)$ & $(1.435)$ & $(1.051)$ & $(1.349)$ & (1.167) & $(1.460)$ & $(1.130)$ & $(1.269)$ \\
\hline Observations & 385 & 385 & 385 & 385 & 439 & 439 & 439 & 439 \\
\hline R-squared & 0.202 & 0.468 & 0.319 & 0.611 & 0.211 & 0.478 & 0.340 & 0.606 \\
\hline Country FE & No & Yes & No & Yes & No & Yes & No & Yes \\
\hline Time FE & No & No & Yes & Yes & No & No & Yes & Yes \\
\hline
\end{tabular}

\section{Classification of Coudert and Dubert (2005)}

The procedure to obtain the de facto exchange rate regime classification of Coudert and Dubert (2005) involves three steps, which are detailed below.

1. Assessing annual trend in the exchange rate. In the first step, the annual trend is extracted by estimating, for each country and each year of our sample, the following regression:

$$
\ln E_{t}=\alpha+\gamma \times t+\varepsilon_{t}
$$


where $\ln E_{t}$ is the logarithm of the monthly nominal exchange rate against the U.S. dollar, $t$ is a linear trend, and $\varepsilon_{t}$ denotes the residual term $(t=1, \ldots, 12)$. Data on nominal exchange rates $E_{t}$ are monthly and are extracted from the IMF International Financial Statistics database. The annual trend for year $j$, denoted by $\hat{\beta}_{j}$, is obtained from the OLS estimate of $\gamma$ as $\hat{\beta}_{j}=(1+\hat{\gamma})^{12}-1$. If $\hat{\beta}_{j}>0$, the series of monthly exchange rates are detrended ( $\tilde{E}_{t}$ denoted the detrended exchange rate in what follows). If the annual trend is negative, its absolute value $\left|\hat{\beta}_{j}\right|$ is compared to an arbitrary threshold $\tau$. Following Coudert and Dubert (2005), $\tau$ is set to $2 \%$ annually.

2. Comparing exchange rate variances. The second step consists in comparing the annual variance of changes in $\Delta E_{t}$ (alternatively $\Delta \tilde{E}_{t}$ if $\hat{\beta}_{j}>0$ in step 1) to the average variance of a benchmark set of floating currencies. The benchmark sample of floating currencies is made up of the Japanese Yen, the British Pound, and the German Deutsche Mark (after 1999, the Euro stands in for the Deutsche Mark). By considering a floating currencies benchmark, we are able to compute Fisher tests applied to the variance of nominal exchange rates. Let $s_{i}^{2}$ denote the empirical annual variance of $\Delta E_{t}$ for the Latin American country $i$, and $s_{b}^{2}$ the average of annual variances of the benchmark. By assuming that annual variances follow normal distributions with theoretical variance $\sigma_{i}^{2}$ ( $\sigma_{b}^{2}$ resp.) for country $i$ (the benchmark group resp.), this implies that the ratio $\left(s_{b}^{2} / \sigma_{b}^{2}\right) /\left(s_{i}^{2} / \sigma_{i}^{2}\right)$ follows a Fisher distribution $F\left(n_{b}, n_{i}\right)$ where $n_{b}$ and $n_{i}$ are the degrees of freedom. $s_{b}^{2}$ and $s_{i}^{2}$ being calculated with 36 and 12 observations respectively, we get $n_{b}=35$ and $n_{i}=11$. The null hypothesis $H_{0}$ is that, for a given year, the variance of exchange rate changes in country $i$ is smaller than that in the benchmark group, i.e. $H_{0}: \sigma_{i}^{2}<\sigma_{b}^{2}$. If $s_{i}^{2}<(1 / 2.54) s_{b}^{2}$, the exchange rate variance of country $i$ is considered as low $(2.54$ being the $5 \%$ critical value of a $F(35,11))$. Conversely, if $s_{i}^{2} \geq(1 / 2.54) s_{b}^{2}$, the variance of country $i$ is treated as high. ${ }^{22}$

3. Comparing changes in international reserves variances. In the final stage, we apply the same test presented in step 2 to the variance of changes in official reserves $\left(\Delta R_{t}\right)$. Data on international reserves $R_{t}$ are monthly and are extracted from the IMF International Financial Statistics database. Accordingly, the empirical variance of changes in foreign reserves for country $i$,

\footnotetext{
${ }^{22}$ During the years 1970-1972, currencies of the benchmark were part of the Bretton Woods system which was characterized by fixed parities against the U.S. dollar and low volatility in nominal exchange rates. Since step 2 is an equality test of exchange rate variance between country $i$ and the benchmark group, the methodology tends to be biased in favor of flexible regimes. Therefore, some spurious observations for years 1970, 1971 and 1972 primarily classified as pure or managed float were converted into a fixed regime to account for the low exchange rate volatility in the benchmark sample.
} 
denoted by $\tilde{s}_{i}^{2}$ with a theoretical value $\tilde{\sigma}_{i}^{2}$, is compared to the average variance of changes in foreign reserves of the benchmark group (noted $\tilde{s}_{b}^{2}$ with a corresponding theoretical value $\tilde{\sigma}_{b}^{2}$ ). Assuming that monthly rates of changes in reserves follow normal distributions, a Fisher test can be computed. In this case, the null hypothesis is that, for a given year, the variance of the reserves changes in country $i\left(\tilde{\sigma}_{i}^{2}\right)$ is higher than that in the benchmark group $\left(\tilde{\sigma}_{b}^{2}\right)$, i.e. $H_{0}: \quad \tilde{\sigma}_{i}^{2}>\tilde{\sigma}_{b}^{2}$. Accordingly, the ratio $\left(\tilde{s}_{i}^{2} / \tilde{\sigma}_{i}^{2}\right) /\left(\tilde{s}_{b}^{2} / \tilde{\sigma}_{b}^{2}\right)$ follows a Fisher distribution $F(35,11)$. If $\tilde{s}_{i}^{2}>2.54 \tilde{s}_{b}^{2}$, the variance of international reserves is considered as high. Otherwise, if $\tilde{s}_{i}^{2} \leq 2.54 \tilde{s}_{b}^{2}$, the variance of international reserves is considered as low.

The classification of Coudert and Dubert (2005), derived from the procedure described above, can be summarized by Table A-8. The corresponding measure of ERR, presented in the last column, is coded as follows: $4=$ peg, $3=$ crawling peg, $2=$ managed float and $1=$ pure float.

Table A-8: Exchange Rate Regimes in Coudert and Dubert (2005)'s classification

\begin{tabular}{l|c|c||c|c}
\hline $\begin{array}{l}\text { Annual Trend } \\
\text { (step 1) }\end{array}$ & $\begin{array}{c}\text { Exchange rate variance } \\
\text { (step 2) }\end{array}$ & $\begin{array}{c}\text { Reserves variance } \\
\text { (step 3) }\end{array}$ & Regime & $\begin{array}{c}\text { Dummy } \\
\text { variable }\end{array}$ \\
\hline$\hat{\beta}>0$ and $\hat{\beta}<\tau$ & low & & peg & 4 \\
$\hat{\beta}<0$ and $|\beta|<\tau$ & low & peg \\
\hline$\hat{\beta}>0$ and $\hat{\beta}>\tau$ & low & high & managed float & 2 \\
\hline$\hat{\beta}>0$ & high & high & managed float & 2 \\
$\hat{\beta}<0$ and $|\beta|>\tau$ & high & managed float & 2 \\
$\hat{\beta}<0$ and $|\beta|<\tau$ & high & low & pure float & 1 \\
$\hat{\beta}>0$ & high & low & pure float & 1 \\
$\hat{\beta}<0$ and $|\beta|>\tau$ & & low & pure float & 1 \\
$\hat{\beta}<0$ and $|\beta|<\tau$ & high & \multicolumn{3}{|c}{}
\end{tabular}

The measure of ERR is available for the 17 countries in our sample and covers the 1970-2016 period. Figure A-1 plots the decade average of the share of fixed exchange rate regimes for the Latin American continent, and separately for each of the regions, i.e., Central America and South America. ${ }^{23}$ The overall pattern is very similar to that of Figure 1. First, in all decades, the share of fixed ERR is higher in Central American countries than in South America. Second, for the whole sample, the percentage of fixed exchange rate regimes declined over time from $58 \%$ in the

\footnotetext{
${ }^{23}$ Consistent with Figure 1 which plots the share of fixed exchange rate regimes in the SHA and IRR classifications for a sample of 16 countries (Ecuador is dropped) over the 1970-2014 period, we use in Figure A-1 the same sample such that the results are comparable across classifications.
} 
1970s to $30 \%$ in the 2010 decade according to the CD classification. However, there are important differences across the two geographical areas. In Central America, the share of fixed EER also significantly decreased (81\% during the 70's to $45 \%$ over the 2010-2014 period). After a sharp decline during the 1970s, this share has remained stable in South America since the 1980s and amounts to 10-15\%.

Figure A-1: Percentage of Fixed Exchange Rate Regimes in Latin American Countries (Coudert and Dubert's classification).

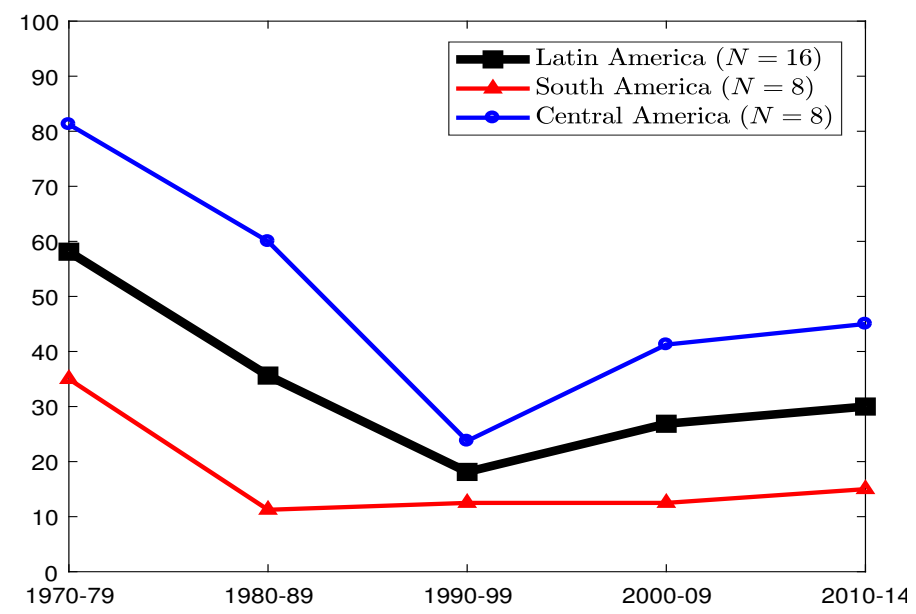

Note: The group of 16 Latin American countries comprises 8 South American countries (Argentina, Bolivia, Brazil, Chile, Colombia, Paraguay, Peru, and Uruguay) and 8 Central American countries (Costa Rica, Dominican Republic, Guatemala, Honduras, Jamaica, Mexico, Panama, and Trinidad and Tobago). Period: 1970-2014. 


\section{References}

Alberola, E. (2003): "Misalignment, Liabilities Dollarization and Exchange Rate Adjustment in Latin America," Working Paper 0309, Banco de Espana.

Amano, R. A., and S. van Norden (1995): "Terms of Trade and Real Exchange Rates: the Canadian Evidence," Journal of International Money and Finance, 14(1), 83-104.

Baum, C. F. (2001): "Residual Diagnostics for Cross-section Time Series Regression Models," The Stata Journal, 1(1), 101-104.

Bénassy-Quéré, A., S. Béreau, and V. Mignon (2010): "On the Complementarity of Equilibrium Exchange-Rate Approaches," Review of International Economics, 18(4), 618-632.

Berka, M., M. B. Devereux, and C. Engel (2012): "Real Exchange Rate Adjustment in and out of the Eurozone," American Economic Review, 102(3), 179-85.

Breusch, T. S., And A. R. Pagan (1980): "The Lagrange Multiplier Test and its Applications to Model Specification in Econometrics," The Review of Economic Studies, 47(1), 239-253.

Buchs, T. (2005): "Equilibrium Real Exchange Rate In Brazil Estimation And Policy Implications," International Trade 0502013, University Library of Munich, Germany.

Caputo, R. (2015): "Persistent Real Misalignments and the Role of the Exchange Rate Regime," Economics Letters, 135, 112-116.

Carrera, J., and G. Vuletin (2013): "The Effects of Alternative Exchange Rate Regimes on Real Exchange Rate Volatility: Evidence Based on a New Dataset," Contemporary Economic Policy, 31(1), 212-234.

Chi-Wei Su, C. T., And H.-L. Chang (2011): "Purchasing Power Parity for Fifteen Latin American Countries: Stationary Test with a Fourier Function," International Review of Economics and Finance, 20(4), 839-845.

Chinn, M. D., And S.-J. Wei (2013): "A Faith-Based Initiative Meets the Evidence: Does a Flexible Exchange Rate Regime Really Facilitate Current Account Adjustment?," The Review of Economics and Statistics, 95(1), 168-184. 
Chudik, A., And M. H. Pesaran (2015): "Common Correlated Effects Estimation of Heterogeneous Dynamic Panel Data Models with Weakly Exogenous Regressors," Journal of Econometrics, 188(2), 393-420.

Comunale, M. (2017): "Dutch Disease, Real Effective Exchange Rate Misalignments and Their Effect on GDP Growth in EU," Journal of International Money and Finance, 73, 350-370.

Coudert, V., and C. Couharde (2009): "Currency Misalignments and Exchange Rate Regimes in Emerging and Developing Countries," Review of International Economics, 17(1), 121-136.

Coudert, V., And M. Dubert (2005): "Does Exchange Rate Regime Explain Differences in Economic Results for Asian Countries?," Journal of Asian Economics, 16(5), 874-895.

Couharde, C., A.-L. Delatte, C. Grekou, V. Mignon, and F. MorvilLIER (2020): "Measuring the Balassa-Samuelson Effect: A Guidance Note on the RPROD Database," International Economics, 161, 237-247.

De Gregorio, J., and H. C. Wolf (1994): "Terms of Trade, Productivity, and the Real Exchange Rate," NBER Working Paper 4807, National Bureau of Economic Research.

Devereux, J., And M. Connolly (1996): "Commercial Policy, the Terms of Trade and the Real Exchange Rate Revisited," Journal of Development Economics, 50(1), 81-99.

Devereux, M. B., and P. R. Lane (2003): "Understanding Bilateral Exchange Rate Volatility," Journal of International Economics, 60(1), 109-132.

Driver, R. L., And P. F. Westaway (2005): "Concepts of Equilibrium Exchange Rates," Bank of England Working Paper 248, Bank of England.

DubAs, J. M. (2009): "The Importance of the Exchange Rate Regime in Limiting Misalignment," World Development, 37(10), 1612-1622.

EDwARDs, S. (1989): "Real Exchange Rates in the Developing Countries: Concepts and Measurement," NBER Working Paper 2950, National Bureau of Economic Research.

(2004): "Financial Openness, Sudden Stops, and Current-Account Reversals," American Economic Review, 94(2), 59-64. 
Edwards, S., And M. A. Savastano (1999): "Exchange Rates in Emerging Economies: What Do We Know? What Do We Need to Know?," Working Paper 7228, National Bureau of Economic Research.

Faruqee, H. (1995): "Long-Run Determinants of the Real Exchange Rate: A Stock-Flow Perspective," IMF Staff Papers, 42(1), 80-107.

Fernando Broner, Norman Loayza, H. L. (2005): "Real Exchange Rate Misalignment in Latin America," Mimeo, The World Bank.

Frenkel, R., And M. Rapetti (2010): "A Concise History of Exchange Rate Regimes in Latin America," Umass amherst economics working papers, University of Massachusetts Amherst, Department of Economics.

Friedman, M. (1953): Essays in Positive Economics. University of Chicago Press.

Froot, K., And K. Rogoff (1995): "Perspectives on PPP and Long-run Real Exchange Rates," in Handbook of International Economics, ed. by G. M. Grossman, and K. Rogoff, vol. 3, chap. 32, pp. 1647-1688. Elsevier.

Gervais, O., L. Schembri, and L. Suchanek (2016): "Current Account Dynamics, Real Exchange Rate Adjustment, and the Exchange Rate Regime in Emerging-Market Economies," Journal of Development Economics, 119, 86-99.

Ghosh, A. R., M. S. Qureshi, and C. G. Tsangarides (2018): "Friedman Redux: External Adjustment and Exchange Rate Flexibility," The Economic Journal, 129(617), 408-438.

Giannellis, N., And M. Koukouritakis (2013): "Exchange Rate Misalignment and Inflation Rate Persistence: Evidence from Latin American Countries," International Review of Economics and Finance, 25, 202-218.

Gnimassoun, B. (2015): "The Importance of the Exchange Rate Regime in Limiting Current Account Imbalances in Sub-Saharan African Countries," Journal of International Money and Finance, 53, 36-74.

Gnimassoun, B., and V. Mignon (2015): "Persistence of Current-account Disequilibria and Real Exchange-rate Misalignments," Review of International Economics, 23(1), 137-159.

Gnimassoun, B., And V. Mignon (2016): "How Macroeconomic Imbalances Interact? Evidence from a Panel VAR Analysis," Macroeconomic Dynamics, 20(7), $1717-1741$. 
Holtemoller, O., and S. Mallick (2013): "Exchange Rate Regime, Real Misalignment and Currency Crises," Economic Modelling, 34, 5-14.

Ibrahim A. Elbadawi, L. K., and R. Soto (2012): "Aid, Real Exchange Rate Misalignment, and Economic Growth in Sub-Saharan Africa," World Development, 40(4), 681-700.

Ilzetzki, E., C. M. Reinhart, And K. S. Rogoff (2019): "Exchange Arrangements Entering the Twenty-First Century: Which Anchor will Hold?," The Quarterly Journal of Economics, 134(2), 599-646.

Lane, P. R., and G. M. Milesi-Ferretti (2001): "The External Wealth of Nations: Measures of Foreign Assets and Liabilities For Industrial and Developing Countries," Journal of International Economics, 55(2), 263-294.

- (2002): "External Wealth, the Trade Balance, and the Real Exchange Rate," European Economic Review, 46(6), 1049-1071.

Lluís Carrion-i Silvestre, J., T. Del Barrio-Castro, and E. LópezBAzo (2005): "Breaking the Panels: An Application to the GDP Per Capita," The Econometrics Journal, 8(2), 159-175.

MacDonald, R., and P. B. Clark (1998): "Exchange Rates and Economic Fundamentals; A Methodological Comparison of BEERs and FEERs," IMF Working Papers 98/67, International Monetary Fund.

Mark, N. C., ANd D. Sul (2003): "Cointegration Vector Estimation by Panel DOLS and Long-run Money Demand," Oxford Bulletin of Economics and Statistics, 65(5), 655-680.

Martin, F. E. (2016): "Exchange Rate Regimes and Current Account Adjustment: An Empirical Investigation," Journal of International Money and Finance, 65, 69-93.

Martin Guzman, J. A. O., And J. E. Stiglitz (2018): "Real Exchange Rate Policies for Economic Development," World Development, 110, 51-62.

MendozA, E. G. (1995): "The Terms of Trade, the Real Exchange Rate, and Economic Fluctuations," International Economic Review, 36(1), 101-137.

Nouira, R., And K. SekKat (2015): "What Determines the Extent of Real Exchange Rate Misalignment in Developing Countries?," International Economics, $141,135-151$. 
Paiva, C. A. (2006): "External Adjustment and Equilibrium Exchange Rate in Brazil," IMF Working Papers 06/221, International Monetary Fund.

Pesaran, M. H. (2007): "A Simple Panel Unit Root Test in the Presence of Cross-Section Dependence," Journal of Applied Econometrics, 22(2), 265-312.

- (2015): "Testing Weak Cross-Sectional Dependence in Large Panels," Econometric Reviews, 34(6-10), 1089-1117.

Ravn, M. O., S. Schmitt-Grohé, and M. Uribe (2012): "Consumption, Government Spending, and the Real Exchange Rate," Journal of Monetary Economics, 59(3), 215-234.

Rodrik, D. (2008): "The Real Exchange Rate and Economic Growth," Brookings Papers on Economic Activity, 2008, 365-412.

Rogoff, K. (1996): "The Purchasing Power Parity Puzzle," Journal of Economic Literature, 34(2), 647-668.

Rose, A. K., B. Lockwood, and D. Quah (2000): "One Money, One Market: The Effect of Common Currencies on Trade," Economic Policy, 15(30), 9-45.

Schrø̈DER, M. (2013): "Should Developing Countries Undervalue Their Currencies?," Journal of Development Economics, 105, 140-151.

Shambaugh, J. C. (2004): "The Effect of Fixed Exchange Rates on Monetary Policy," The Quarterly Journal of Economics, 119(1), 301-352.

Westerlund, J. (2007): "Testing for Error Correction in Panel Data," Oxford Bulletin of Economics and Statistics, 69(6), 709-748.

Williamson, J. (1983): The Exchange Rate System. Institute for International Economics, Washington, DC, MIT Press, Cambridge, MA.

Zeev, N. B., E. Pappa, And A. VicondoA (2017): "Emerging Economies Business Cycles: The Role of Commodity Terms of Trade News," Journal of International Economics, 108, 368-376. 